\title{
Transport legacy of mega-events and the redistribution of accessibility to urban destinations
}

\begin{abstract}
Local governments increasingly justify the hosting of mega-events because of their legacy value, assuming that all local residents benefit from those events. Yet, little attention has been paid to the distributive question of who benefits from the transport legacy left by those events. This paper reflects on the delimitation of transport legacies and its social impacts in terms of how such developments can reshape urban accessibility to opportunities. It analyses the transformation in the transport system of Rio de Janeiro (Brazil) in preparation for the 2014 World Cup and the 2016 Olympic Games. That transformation involved substantial expansion in public transport infrastructure, followed by cuts in service levels and a reorganization of many bus lines to streamline the transport system. The paper examines whether those recent changes have increased the number of people from different income levels who could access Olympic sports venues and healthcare facilities by public transport within 15, 30, 60 and 90 minutes. The analysis uses a before-and-after comparison of Rio’s transport network (2014-2017) and a quasi-counterfactual scenario to separate the effects of newly added infrastructure from the reorganization and cuts of transport services. The results show that the infrastructure expansion alone would have increased the number of people who could access the Olympic sports venues, but it would have only marginally improved people's access to healthcare facilities. Nonetheless, the findings indicate that the streamlined bus system have offset the benefits of infrastructure investments in a way that particularly penalizes the poor. The analysis of both the implemented changes to the public transport network and the counterfactual scenario show that the accessibility benefits from the recent cycle of investments and disinvestments in Rio generally accrued to middle- and higherincome groups, reinforcing existing patterns of urban inequality.
\end{abstract}

Keywords: mega-events, legacy, Rio de Janeiro, transport investments, accessibility, equity, sociospatial inequalities, Olympic Games, distributional impacts 


\section{Introduction}

There is a growing debate about whether sports mega-events, such as the FIFA World Cup and the Olympic Games, can foster urban development in host cities by boosting their local economies and leveraging investments in infrastructure (Chalkley \& Essex, 1999; Gratton et al., 2005; Hiller, 2000a). The infrastructure projects associated with such events and its promised legacy usually play a key part in the justification used by local and national governments in bids for hosting megaevents (Paddison, 1993; Rubalcaba-Bermejo \& Cuadrado-Roura, 1995; Zhang \& Zhao, 2009).

The strategy of using mega-events to fast-track urban development is commonly backed by pro-growth discourses (Burbank et al., 2002), which rely on the assumption that all local residents invariably benefit from the trickle-down effects of economic growth and improvements to urban infrastructure (Baade, 1996; Baade \& Matheson, 2004; Jones, 2001; Kasimati, 2003; Müller, 2015). Yet, this assumption has been questioned by several studies, which claim that the evaluation of the legacy of sports mega-events should incorporate an equity perspective of how the benefits and burdens of their purported legacies are distributed (Horne \& Manzenreiter, 2006; Smith, 2009). Various studies, for example, have also noted how the organization of mega-events often leads to negative impacts on local communities. In many occasions, thousands of families have had to be evicted from their homes to make room for new infrastructure (Armstrong et al., 2011; Shin \& Li, 2013; Vanwynsberghe et al., 2013), mega-events have caused significant environmental impacts (Collins et al., 2007, 2009; Death, 2011; Gaffney, 2013), they have bypassed democratic decision-making processes (Andranovich et al., 2001; Gold \& Gold, 2011; Raco, 2014; Roche, 1994) and they have concentrated economic and political power in the hands of small interest groups attempting to rewrite urban planning priorities (Broudehoux, 2007; Sánchez \& Broudehoux, 2013).

However, scholars have devoted much less attention to the equity implications of the transport legacies of mega-events, overlooking the distributive aspects of who benefits from these new transport developments ${ }^{1}$. Most of the literature on mega-events and urban transport has

\footnotetext{
1 The terms equity and distributive justice are used interchangeably throughout this paper. The idea of justice is a broader concept that encompasses moral and political concerns related to (1) how benefits and burdens are distributed
} 
focused on the short-term challenges of delivering transport services during the actual events - in terms of traffic management and contingency plans to address peak demand and congestion (Currie \& Shalaby, 2012; Hensher \& Brewer, 2002; Liu et al., 2008; Mao, 2008; Minis \& Tsamboulas, 2008; Robbins et al., 2007; Silva \& Portugal, 2016; Xu \& Gonzalez, 2016). Only a handful of studies have focused on the lasting transport benefits derived from mega-events (Kassens-Noor, 2012), and little attention has been paid to how these transport legacies subsequently change the daily transport conditions of local residents from different social groups (see section 2).

This paper focuses on the distributional effects of the transport legacies of mega-events looking at how such investments affect different income groups' access to Olympic sports sites and health-care facilities in host cities. It analyzes the city of Rio de Janeiro (Brazil), where transport planning has been largely driven by mega-events for almost two decades (Kassens-Noor et al., 2016). In particular, the study looks at the transformations implemented in the city's public transport system in preparation for the 2014 World Cup and the 2016 Olympic Games, which included two new high-capacity Bus Rapid Transit (BRT) corridors, a new light-rail system, and a subway extension. These investments were also followed by a reorganization of bus lines to streamline the transport network and, more recently, by cuts in service levels in response to a drop in passenger demand (see section 3).

In the empirical analysis, a before-and-after comparison of Rio's transport system between 2014 and 2017 were conducted to calculate how the newly implemented transport investments and subsequent reorganization of the transport system have changed the number of people from different income groups who could access Olympic sports venues and healthcare facilities in the city. A quasi-counterfactual analysis was also conducted to investigate how these results would have been different had the expansion of public transport infra-structure in Rio had not been followed by a reorganization of bus lines. Census data and geolocated timetables of public transport services were combined to calculate the catchment areas of sports venues and healthcare facilities in terms of how many people from different income groups can reach those locations from their homes within 15, 30, 60 and 90 minutes using only public transport and walking. This allowed to estimate how recent modifications in Rio’s public transport system have changed the

in society (distributive justice); (2) the fairness of processes and procedures of decision (procedural justice); and (3) the recognition of rights and entitlements (Fainstein, 2010; Pereira et al., 2017). 
size and income composition of the catchment areas of those facilities and to compare how accessibility gains vary across different income groups and areas of the city.

Olympic sports facilities have been chosen because they have immediate connection to the new transport projects in the city and because improving people's access to such venues is a key condition to promote sports participation and leave a sports legacy (Weed et al., 2015), which was one of the main goals purported by local authorities in their bids to host the Olympics (Rio de Janeiro, 2016). Health services were chosen for the analysis in this paper because they play an important role in the satisfaction of people's basic needs. Health services are considered in Brazil to be a basic constitutional right that should be accessible to all, regardless of personal income. Assessing the impacts of Rio' transport legacy on people's access to educational and employment opportunities would be equally important and this investigation is being developed on a separate study (Pereira et al., 2017).

A distributive justice discussion on who benefits from the transport legacies of megaevents is important for several reasons. These events require substantial public funds be directed to infrastructure investments, but the local population generally has little involvement in the relevant decision-making processes. Project evaluations of mega-events and transport investments are traditionally conducted using a cost-benefit analysis framework (Flyvbjerg \& Stewart, 2012), which has been widely criticized for not taking into account the distributive aspects of who reaps the benefits and who bears the costs of such investments (Van Wee, 2012). Moreover, the transport legacies of such events can substantially change the organization of urban space, making it crucial to evaluate whether local governments mobilize these events in a way that redresses or reinforces existing patterns of urban inequality and segregation.

The remainder of this paper is divided into five parts. The next section reviews the concept of legacy as it is used in the mega-events literature and discusses how it translates into transport legacy and connects to transportation equity. Section 3 presents the context of Rio de Janeiro and the changes implemented to its transport system in the context of recent sports mega-events. Sections 4 and 5, respectively, present the data sources and methods used in the analysis and discuss the results. Section 6 presents the paper's conclusions. 


\section{Mega-events, urban development and transport legacy}

The idea of leveraging mega-events to fast-track urban development and create lasting benefits for host cities has gradually been incorporated into the mega-events agenda and governments' discourse over the past decades (Gold \& Gold, 2008; Leopkey \& Parent, 2012; Tomlinson, 2014). In 2003, the International Olympic Committee (IOC) started officially requesting that candidate cities include legacy concerns in their bid proposals. The word legacy, however, often lacks conceptual consistency in bidding documents and across the academic literature (Andranovich \& Burbank, 2011; Cornelissen et al., 2011; Preuss, 2007). One comprehensive definition of legacy embraces "the material and non-material effects produced directly or indirectly by the sport event, whether planned or not, that durably transform the host region in an objectively and subjectively positive or negative way." (Chappelet \& Junod, 2006, p.5).

Different authors generally recognize that legacy impacts tend to be greater in areas that are physically closer to the event sites and that they are more difficult to identify in the long term (Cornelissen et al., 2011; Preuss, 2007). The durable nature of legacies is the most prominent feature emphasized in the literature (Cornelissen et al., 2011; Gratton et al., 2005). Nonetheless, the definition of what qualifies as short or long term is often vaguely defined in cities' bids and in the literature, and yet this issue of temporal scale is crucial when assessing legacy impacts (ibid.). Kassens-Noor $(2010,2013)$ notes, for example, that only a few of the transport measures adopted during the Olympic Games between 1992 and 2012 (Barcelona, Atlanta, Sydney, Athens and London) have been sustained beyond the immediate years following the Games. Consideration of the spatial dimension of mega-event legacies is also particularly important when addressing concerns about their equity implications. Specifically, how are the benefits and costs of megaevents distributed across groups and neighborhoods in host cities? Official pro-poor discourses surrounding the transport legacy of the 2010 FIFA World Cup in South Africa, for example, were challenged by Pillay and Bass (2008), who claimed that improvements to the transport system would be spatially concentrated and offer limited benefits to peripheral urban areas.

All too often there are discrepancies between the plans laid down in bid books and the legacies that are left after the events (Stewart \& Rayner, 2016). Müller (2015) points to a "mega- 
event syndrome” and its seven interrelated "symptoms” that affect the planning of mega-events and which help explain why delivered legacies fall short of the promises made to local communities. These problems involve the overpromising of benefits, the underestimation of costs, the displacement of local development priorities by the events' agenda, the suspension of regular rule of law, a naive belief that mega-events could work as quick fixes for major planning challenges, the use of public funds to cover the risks of projects with limited public benefits, and the capture of decision-making processes by economic and political elites. According to the Müller (2015), these issues are present to a greater or lesser degree in the organization of mega-events worldwide and commonly lead to lead to the bypassing of regular planning processes and inequitable distributions of public funds and urban infrastructure. Together, these symptoms and their consequences raise serious questions about democratic accountability and call into question whether the logics of mega-event legacy planning are practically and functionally compatible with more egalitarian notions of urban policy.

Although mega-events are often justified with reference to their role in addressing urban inequity, these events have generally brought questionable benefits to socially disadvantaged groups (Hiller, 2006; Minnaert, 2012; Smith, 2009). Concerns over distributive justice focusing on who benefits from mega-event legacies have generally received little attention in assessments of the impacts of mega-events (Short, 2008; Whitson \& Horne, 2006). In part, this relates to a common practice of event promoters, who emphasize only the positive legacies of such events, despite the negative impacts they frequently have on local communities (Essex \& Chalkley, 2004; Hiller, 2006; Müller, 2015; Preuss, 2007). However, when assessing the equity impacts of megaevents, it is necessary to acknowledge that the benefits and costs arising from their legacies are rarely equally distributed among members of society and that the same legacy might have positive effects for some groups and negative effects for others (Chappelet, 2012). In the case of the 2016 Olympics in Rio de Janeiro, for example, public authorities used a utilitarian argument that the wider benefits of infrastructure investments would outweigh their social and environmental costs, thus justifying the evictions of more than two thousand families to create space for the new transport investments (Legroux, 2014). Before discussing the case of Rio de Janeiro, the next section outlines how the transport legacies and their equity implications can be framed within a distributive justice perspective. 


\subsection{Transport Legacy and accessibility}

Mega-event legacies affect different but interrelated aspects of urban development, such as the economy, knowledge and skill development, physical infrastructure, city image/reputation, and the environment (Andranovich \& Burbank, 2011; Gratton \& Preuss, 2008; Ritchie, 1984). Regarding urban transportation in particular, Kassens-Noor (2010) argues that transport legacies can be created either in the form physical and infrastructural changes to the transport systems of host cities or in the form of how these systems are governed and managed . In the first case, megaevents can create some form of transport legacy by driving changes in management practices, regulation and institutional policies, including, for example, the adoption of Intelligent Transport Systems (ITS), the creation of traffic management centers (TMC), the reorganization of transit routes and the integration of transport modes and tariff systems. In the second case, mega-events can lead to or fast-track more tangible physical changes in the transport system, such as through the renovation of public transport fleets or the building or expansion of transport infrastructure such as roads, subway systems and airports (ibid.).

Most previous studies on transport legacy have focused on questions about the extent to which the short-term view of mega-events has influenced/dominated the long-term transport planning in host cities (Kassens-Noor, 2010, 2013; Kassens-Noor et al., 2016; Legroux, 2014; Rodrigues \& Legroux, 2015). Although there is a general consensus in the literature of the importance of aligning transport projects related to mega-events with the long-term developmental goals of host cities (Hiller, 2000b; Müller, 2015; Pillay \& Bass, 2008; Steinbrink et al., 2011; Tomlinson, 2014), these projects should not be planned as ends in themselves. These projects only become valuable to the extent that they improve living conditions in the communities where they are implemented (Banister, 2002; Cervero, 2013). This can be achieved, for example, when these investments contribute to making transport systems more environmentally sustainable, safe, inclusive and efficient, thus improving the everyday transport conditions of local residents and their environment. A major component of transport legacy relies therefore on the effectiveness of transport projects in improving urban accessibility. 
Accessibility can be broadly conceptualized as the ease with which people can reach places and opportunities, or, conversely, a characteristic of places and opportunities that describes how easily they can be reached by the population (Neutens et al., 2010). Transport accessibility is thus considered critical for individuals to reach out-of-home activities in order to satisfy basic needs; it is a necessary, although not sufficient, condition for expanding people’s freedom of choice and promoting equality of access to opportunities such as employment, healthcare, education, etc. (Lucas, 2012). When evaluating the impact of transport legacy, it thus becomes critical to understand the impact of those investments in making essential services and daily life activities more easily accessible to people, and particularly whether those investments contribute to minimizing or exacerbating socio-spatial inequalities in access to opportunities (Lucas et al., 2015; Pereira et al., 2017; Van Wee \& Geurs, 2011).

The distributional effects of institutions and policies on social inequalities are the primary concern of one of the most influential theories of social justice, proposed by John Rawls (Rawls, 1999, 2001), and feature as a central aspect of justice in urban planning (Basta, 2015; Fainstein, 2010; McKay et al., 2012). In a recent paper, Pereira et al (2017) put forward an interpretation of how Rawls' two principles of justice can be applied to evaluate the fairness of transport policies, which can be extended to the transport legacy of mega-events. According to this interpretation, Rawls’ first principle implies that transport projects can only be considered fair if they respect people's basic rights and liberties, such as the rights and liberties covered by the rule of law, and the physical and psychological liberty and integrity of the person. This means that the sacrifice of people's rights and liberties (for example, the forced eviction of families to create space for the implementation of transport projects) cannot be morally justified on the grounds of improving infrastructure development. Following Rawls' second principle of justice, Pereira et al (2017) argue that, while new transport investments have an important role in improving general transport conditions in cities, they should prioritize improving the accessibility of disadvantaged groups such as low-income and transit-dependent people, the elderly and the disabled - and thus contribute to the reduction of inequality of opportunities (ibid.).

Despite the universal character of Rawls's theory, its application to the assessment of urban planning (Fainstein, 2010; McKay et al., 2012) and transport policies (Pereira et al., 2017; Van Wee \& Geurs, 2011) must account for the specificities of how new projects are implemented in 
each context. In the following sections, I discuss the equity implications of the new transport investments recently implemented in the city of Rio.

\section{The transport legacy of Mega-events in Rio de Janeiro}

Rio de Janeiro is one of the largest and richest urban areas in the Global South, with over 12 million inhabitants. It is also among the most unequal cities in the world in terms of income distribution (UN-HABITAT, 2010), having experienced increasing income inequality in recent decades (Ipea, 2016) and historical spatial segregation (Préteceille \& Cardoso, 2008; Ribeiro et al., 2010). Most of the population of Rio also faces extremely poor transport conditions. The city's public transport system stands out as one of the most expensive in the world (UN HABITAT, 2013) and is coupled with a substantial increase in car traffic, giving Rio one of the highest average commute times among global cities (Pereira \& Schwanen, 2013). Urban mobility conditions in Rio are further aggravated by a complex institutional and governance context marked by fragmentation of responsibilities and jurisdiction regarding transport policies and data collection at the metropolitan scale (Costa et al., 2015). Because of the absence of detailed transport information for the whole of the metropolitan area, the current study considers the city of Rio only, which includes 53\% of the metropolitan area's population.

Rio's history of bidding to host mega-events is characterized by heavy emphasis on using such events as opportunities to accelerate urban development and overcome persistent urban problems (Gaffney, 2010; Silvestre, 2012). The adoption of this mega-event strategy in Rio dates at least to the mid-1990s, with the elaboration of the city's strategic plan in 1996 and the 1997 bid to host the 2004 Olympic games (Rio de Janeiro, 1996; Santos, 2013). Since then, Rio won the bids to host the 2007 Pan-American Games, the 2014 FIFA football World Cup and the 2016 Summer Olympic Games (BOC, 2009; Brazil, 2009; Rio de Janeiro, 2008). Most of these sporting events have taken place in one of four areas of the city in which the Olympic sports venues were clustered (Figure 1). 
Figure 1. Spatial distribution of population, Olympic Sports Venues and high capacity transport corridors. Rio de Janeiro, 2010.

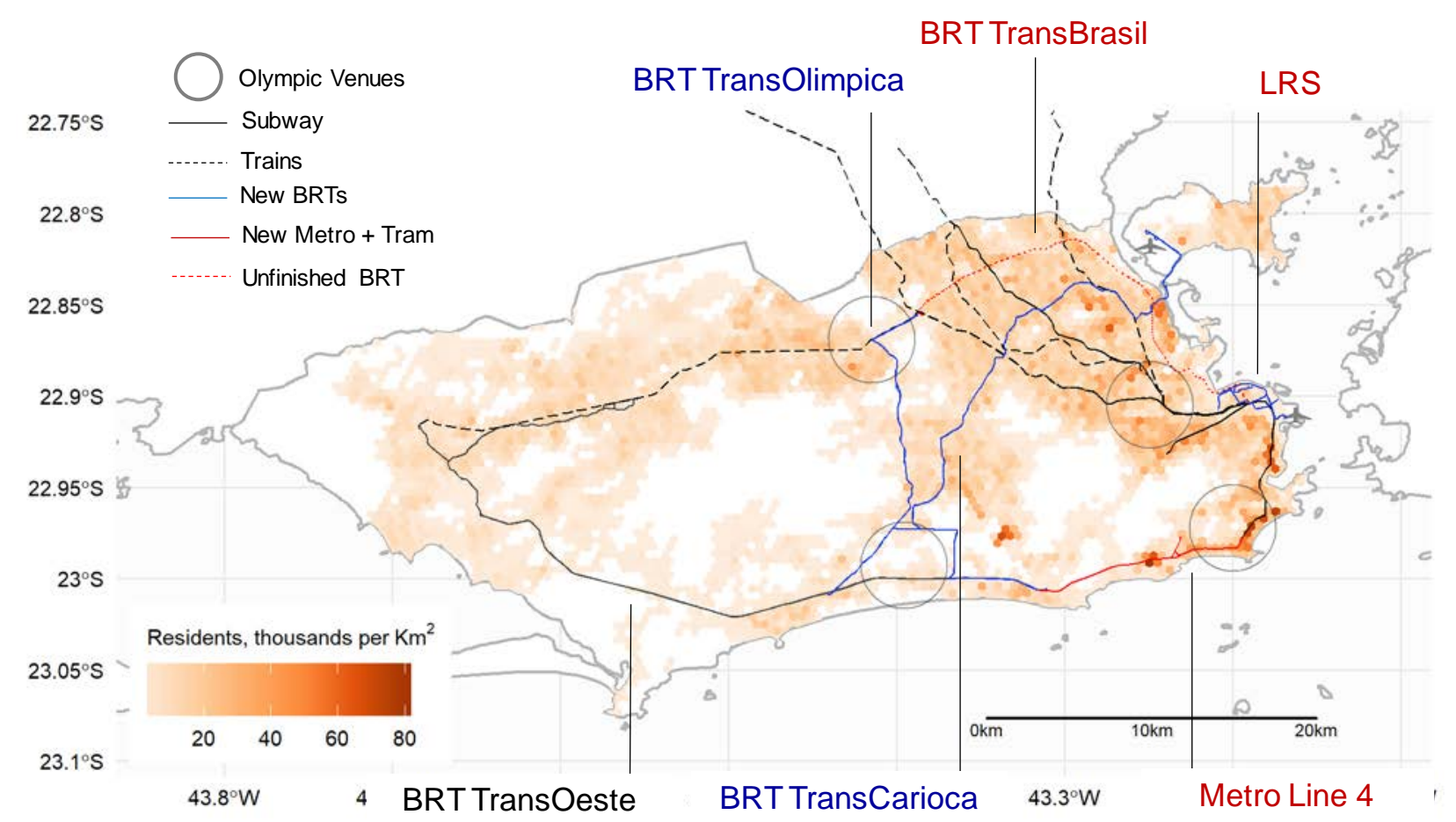

Note: The TransBrasil BRT corridor was originally included in the transportation plans for the 2016 Olympic Games. It was unfinished as of the writing of this paper

These events mobilized an investment of approximately U\$5.7 billion in the city’s public transport system between 2010 and 2016. Some of the most significant transformations in Rio's transport system since 2014 include the construction of a light-rail system in the city center, two new BRT corridors and the expansion of a subway line that, combined, form a high-capacity transport ring connecting several neighborhoods across the city, two airports and the Olympic sports venues. Along with these investments, local authorities have also reorganized many bus lines to accommodate the newly added infrastructure and streamline the transport system. More recently, however, these changes have been followed by a severe economic crisis coupled with a drop in the number of passengers in the public transport system (França, 2016; Rodrigues, 2017). This has led the government to reorganize the transport system and reduce service levels. In total, 
70 bus routes were withdrawn, 41 routes were rerouted or shortened, and 16 new routes were created (G1, 2017).

This subsequent reorganization of bus services raises serious concerns about what will be the actual impact of recent transport investments and who will benefit from them. Perhaps more importantly, it also raises the question of what should be considered as the transport legacy of mega-events. On one hand, a narrow understanding of legacy would only include the actual investments and infra-structure expansion related to the mega-events. From a broader perspective, however, the legacy of those investments cannot be separated from questions of opportunity costs and the wider evolution of the transport network in the city because some of the reorganization of bus services has been implemented in order to accommodate the newly added infrastructure. In the case of Rio, the answer to this question is not trivial particularly because it is not possible to disentangle how much of the reorganization of bus lines was a response to new infrastructure and how much responded to the economic crisis. I return to this question in the empirical analysis where a quasi-counterfactual analysis was used to isolate the effects of the new infrastructure expansion.

From a historical point of view, it is important to note that the transport investments included in Rio’s 2009 Olympic bid file are not completely disconnected from the city’s previous urban plans. The increasing investments in Barra da Tijuca can be considered part of a long historical process of decentralizing economic activities towards the western part of the city, a process that started in the late 1960s with the Barra Pilot Plan (Rezende \& Leitão, 2003). Most of the transport investments described in the bid are generally located in regions of the city that had already been identified as structural transport corridors in previous city plans since 1965 (Table 1), although more fragmented and with different choices of transport modes and routes (Herdy, 2012). The metropolitan transport plan of 2005 (Rio de Janeiro, 2005), for example, proposed that (in an ideal scenario) all structural transport corridors of the city would be covered by a subway system. According to Santos (2013) and Kassens-Noor et al (2016), who interviewed different managers from the city's transport department and the Olympic Public Authority, the routes chosen for investment and the choice to build BRT corridors instead of subways were largely influenced by the Olympic authorities, who were wary of the costs and time horizon required to deliver the investments in time for the event. 
Table 1. Summary of new public transport investments. Rio de Janeiro, 2012-2016. ${ }^{2}$

\begin{tabular}{|c|c|c|c|c|c|c|c|c|c|c|c|c|c|}
\hline \multirow{2}{*}{ New infrastructure } & \multicolumn{8}{|c|}{$\begin{array}{l}\text { City Plans and Bids that metion each transport } \\
\text { corridor * }\end{array}$} & \multirow{2}{*}{$\begin{array}{l}\text { Length } \\
(\mathrm{Km})^{\mathrm{a}}\end{array}$} & \multirow{2}{*}{$\begin{array}{c}\text { Number of } \\
\text { Stations } \\
\text { and } \\
\text { terminals }\end{array}$} & \multirow{2}{*}{$\begin{array}{c}\text { Total Cost } \\
\text { (U\$ Billion) } \\
\text { a }\end{array}$} & \multirow{2}{*}{$\begin{array}{c}\text { Population in } \\
\text { thousands } \\
\text { within } 1 \mathrm{Km}^{\mathrm{c}}\end{array}$} & \multirow{2}{*}{$\begin{array}{l}\text { Start Date of } \\
\text { partial or full } \\
\text { Operation }\end{array}$} \\
\hline & 1965 & 1992 & 1996 & 2005 & 2009 & 2011 & 2013 & 2015 & & & & & \\
\hline BRT Transoeste & & $\mathrm{x}$ & & & & $\mathrm{x}$ & $\mathrm{x}$ & & 58 & 63 & 0.35 & 368.7 & Jun 2012 \\
\hline BRT Transcarioca & $\mathrm{x}$ & $\mathrm{x}$ & $\mathrm{x}$ & $\mathrm{x}$ & $\mathrm{x}$ & $\mathrm{x}$ & $\mathrm{x}$ & & 39 & 47 & 0.55 & 667.1 & Oct 2014 \\
\hline BRT Transolimpica & & $\mathrm{x}$ & & & $\mathrm{x}$ & $\mathrm{x}$ & $\mathrm{x}$ & $\mathrm{x}$ & 26 & 21 & 0.73 & 171.8 & Ago 2016 \\
\hline Subway Line 4 & $\mathrm{x}$ & $\mathrm{x}$ & & $\mathrm{x}$ & & $\mathrm{x}$ & $\mathrm{x}$ & $\mathrm{x}$ & 16 & 7 & $3.11^{b}$ & 163.8 & Sep 2016 \\
\hline Light Rail System & & & & & & & $\mathrm{x}$ & $\mathrm{x}$ & 28 & 32 & $0.50^{b}$ & 66.5 & Aug 2016 \\
\hline BRT TransBrasil & & & & $\mathrm{x}$ & & $\mathrm{x}$ & $\mathrm{x}$ & & 28 & 27 & $0.48^{b}$ & 565.5 & Exp Oct 2018 \\
\hline Total & & & & & & & & & 195 & 205 & 5.72 & $1,282.7$ & - \\
\hline
\end{tabular}

Source: a. (Rio de Janeiro, 2015, 2016); b. (Mello, 2016) c. Total population living within one Km buffer around transport stops using Euclidean distance. Currency rate of 3.12 R\$ to $1 \mathrm{U \$}$.

* City plans and bids:

1965 - Doxiadis Plan

1992 - City Master Plan

1996 - City Strategic Plan

2005 - Master Plan for Urban Transport of Rio Metropolitan area

2009 - Bid file for the Olympic Games 2016

2013 - City Strategic Plan 2013-2016

2015 - Public Policy Olympics Legacy Plan

Since their opening, these new projects have already received substantial criticism from academics, grass roots movements and the media, according to whom these projects are over budget and under investigation for possible corruption (Cuadros, 2016; Fonseca, 2017; Sandy, 2016). Moreover, those Olympic projects were elaborated with little social participation and transparency (Sánchez \& Broudehoux, 2013) and they do not tackle the wider transport needs of the metropolitan area as a whole (Kassens-Noor et al., 2016; Rodrigues \& Legroux, 2015). After performing local inspections and a series of workshops and interviews with local authorities and users, the Institute for Transportation and Development Policy also observed that many BRT stations present barriers to people with physical disabilities, that buses are frequently overcrowded, and that BRT corridors on the whole are still poorly integrated with other transport modes, particularly bicycles (Hughes \& Leshner, 2013; ITDP Brasil, 2013, 2014, 2015). Although these issues are not addressed in this study, they play a central role in creating a more just and inclusive transport system that should be recognized in a broader discussion about transport legacy.

\footnotetext{
${ }^{2}$ These figures do not include the costs of roads nor airport investments, which predominantly cater to highly mobile high-income earners (Müller, 2015).
} 
Furthermore, grass-roots organizations and the press have also denounced the violation of the human rights of local communities who were evicted from their homes - often with coercive and violent practices - to create space for infrastructural projects related to mega-events in the city (CPCORJ, 2015; Kommenda, 2016). Despite modifications of the transport projects to minimize the number of evictions, 2,125 families were relocated because of transport investments between 2009 and 2015, according to official figures (Rio de Janeiro, 2015). Figure 2 depicts the locations of the evictions enforced between 2009 and 2012, showing how affected families were largely concentrated along the routes of the transport investments. From a social justice standpoint, these evictions are in direct conflict with Rawls's first principle of justice, according to which the violation of individuals' basic rights and liberties could not be justified on the grounds of a "greater good". ${ }^{3}$

Figure 2. Evictions in the city of Rio de Janeiro between 2009 and 2012*.

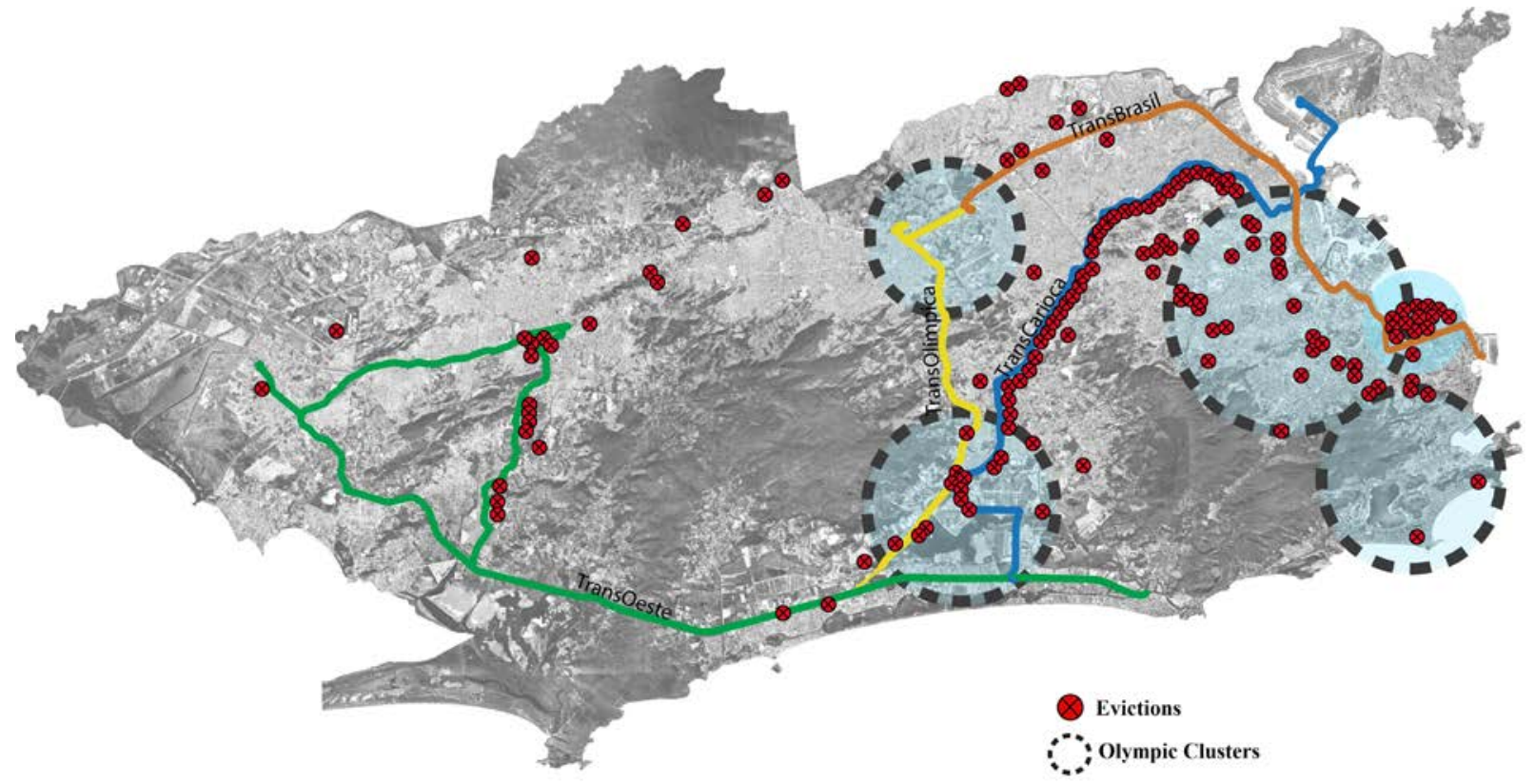

Source: Faulhaber and Nacif (2013, p.4), based on local government decrees published between January 2009 and May 2012.

\footnotetext{
${ }^{3}$ From a Rawlsian perspective, the relocation of families in and of itself would not necessarily be considered a violation of justice as long as relocations resulted from a consensual agreement between the government and relocated families with proper compensation. However, it is difficult to determine the consensual character of transactions involving extreme asymmetries of power and, as in the case of Rio, where evictions have reportedly involved physical and psychological violence by the police (CPCORJ, 2015; Gaffney, 2016; Kommenda, 2016).
} 
A question that has received far less attention, however, is how these investments have changed the transport system of the city overall and how they have made key urban activities more or less accessible to different income groups in the city. While Brazilian public authorities and the Olympic evaluation commission claimed that the transport legacy would particularly benefit low income people who live in deprived areas in distant neighborhoods by reducing the time they spend in traffic (Brazil, 2009), others claimed that such investments were likely to exacerbate social polarization and benefit rich neighborhoods (Brownill et al., 2013; Gaffney, 2010). In the next section, the method used to address this question is explained, considering the recent changes implement in Rio’s public transport system and its network effects on transport accessibility.

\section{Data and Methodology}

Accessibility is here understood as a place characteristic related to how easily a destination can be reached by different social groups. This focus allows us to grasp the broader socio-spatial impacts of transport policies in terms of the access they provide to different types of services and opportunities. The analysis uses a before-and-after comparison of Rio’s public transport system to capture the extent to which the transport legacy of mega-events have changed socio-spatial inequalities in access to sports venues and healthcare services in the city of Rio de Janeiro between 2014 and 2017.

Catchment area analysis was used to estimate the number of people from different income groups who can reach the relevant locations from their homes within a certain travel time threshold using only public transport and walking. I deploy a modified version of a cumulative-opportunity measure, one of the most commonly used accessibility metrics that makes very few assumptions about the nature of people's preferences and behavior (Neutens et al., 2010) and is easy both to implement and interpret (Neutens, 2015; Van Wee \& Geurs, 2011). Although other conceptualizations and measurements of accessibility could have been used, they would offer less detailed insight into the specific destinations that can be reached. They generally require more data on people's observed travel behavior and they are more computationally difficult to both implement and to be interpreted; their use is left for future research. The affordability of public 
transport was not considered in the analysis due to data availability constraints. This is a major limitation to be addressed in future research.

\subsection{Data sources}

This study combines five data sources (Table 2). Demographic and socioeconomic data on Rio's resident population come from the 2010 Census (IBGE, 2010). Population count data from the Census (IBGE, 2016) were organized in a hexagonal grid of 500 by 500 meters, with 5,520 cells. The resident population in each grid cell was categorized according to income decile based on the average household income per capita of each grid cell. This was imputed from census data organized in 1,136 relatively homogeneous socioeconomic polygons known as Human Development Units (Ipea et al., 2015). The data on household income per capita collected in the census account for all members of the household and all their sources of income (including formal or informal jobs, unemployment benefits, pensions, social transfers, etc.). Although the census has some limitations in terms of capturing the upper extreme of income distribution (Souza, 2015), it is still the best data source to account for income distribution in Brazil.

\section{Table 2. Data sources used in the empirical analysis}

\begin{tabular}{|c|c|c|c|}
\hline Data & Details & Source & Year \\
\hline Population - Count & Spatial distribution of population count & Population Census (IBGE) ${ }^{1}$ & 2010 \\
\hline $\begin{array}{l}\text { Population - socioeconomic } \\
\text { characteristics }\end{array}$ & $\begin{array}{l}\text { Spatial distribution of socioeconomic } \\
\text { characteristics }\end{array}$ & $\begin{array}{l}\text { Ipea et al. (2015) based on the } 2010 \\
\text { Population Census (IBGE) }\end{array}$ & 2010 \\
\hline Healthcare facilities & Location and service complexity & $\begin{array}{l}\text { Rio data portal }{ }^{3} \text { Datasus portal } \\
\text { portal }^{4}\end{array}$ & 2015 \\
\hline Street newtork & Roads and pedestrian network & Open Street Maps ${ }^{5}$ & 2017 \\
\hline Public Transport system & $\begin{array}{l}\text { Geolocated time-tables organized in GTFS } \\
\text { format }\end{array}$ & Fetranspor ${ }^{6}$ & 2011, 2014 \\
\hline
\end{tabular}

Note: most of the datasets are publicly available at (1) www.ibge.gov.br (2) www.atlasbrasil.org.br (3) http://data.rio/ (4) www.tabnet.datasus.gov.br (5) www.openstreetmap.org ; (6) Federation of Passenger Transport Companies in Rio de Janeiro 
Geolocated data of the Olympic sports venues (Figure 3) and healthcare facilities (Figure 4) were downloaded from Rio’s open data portal. The analysis included 304 healthcare facilities providing primary and ambulatory care and hospital services free of charge through the public health system (SUS). Health care facilities are categorized in SUS according to the level of complexity of the services they provide according to the costs and technological complexity involved (Brazil, 2007). Low-complexity services include, for example, basic dental treatment, general practice and rehabilitation, while services such as diagnostic radiology, prosthesis and small surgeries are considered of medium complexity. High complexity services, in turn, include neurosurgeries, hemodialysis, intensive care and cancer treatment, among others. According to the data, some facilities provide health services at more than one level of complexity, in which case the facility was included in the accessibility analysis at both levels.

Figure 3. Spatial distribution of Olympic Sports Venues. Rio de Janeiro, 2016.

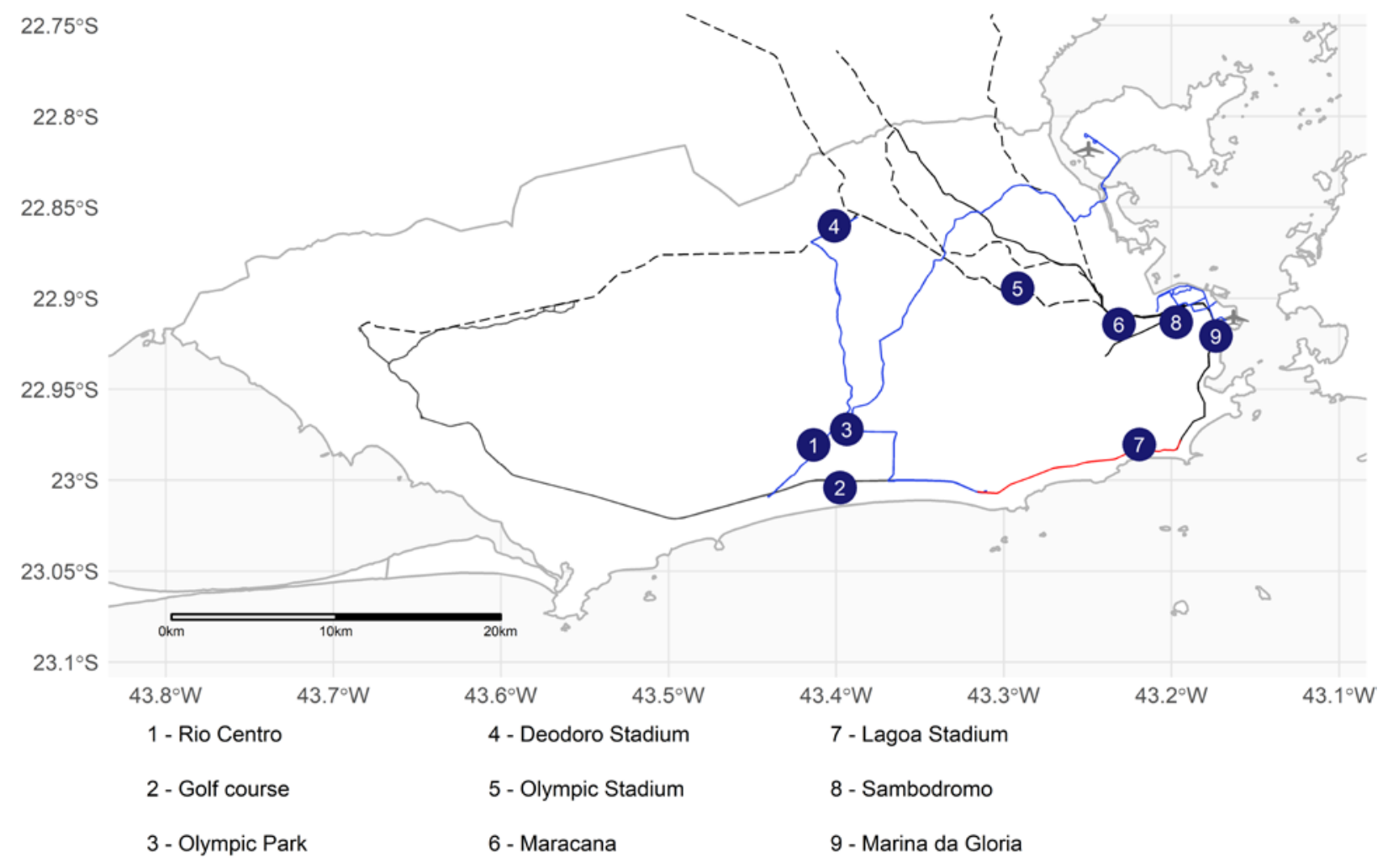


Figure 4. Spatial distribution of healthcare facilities by level of service complexity. Rio de Janeiro, 2015.

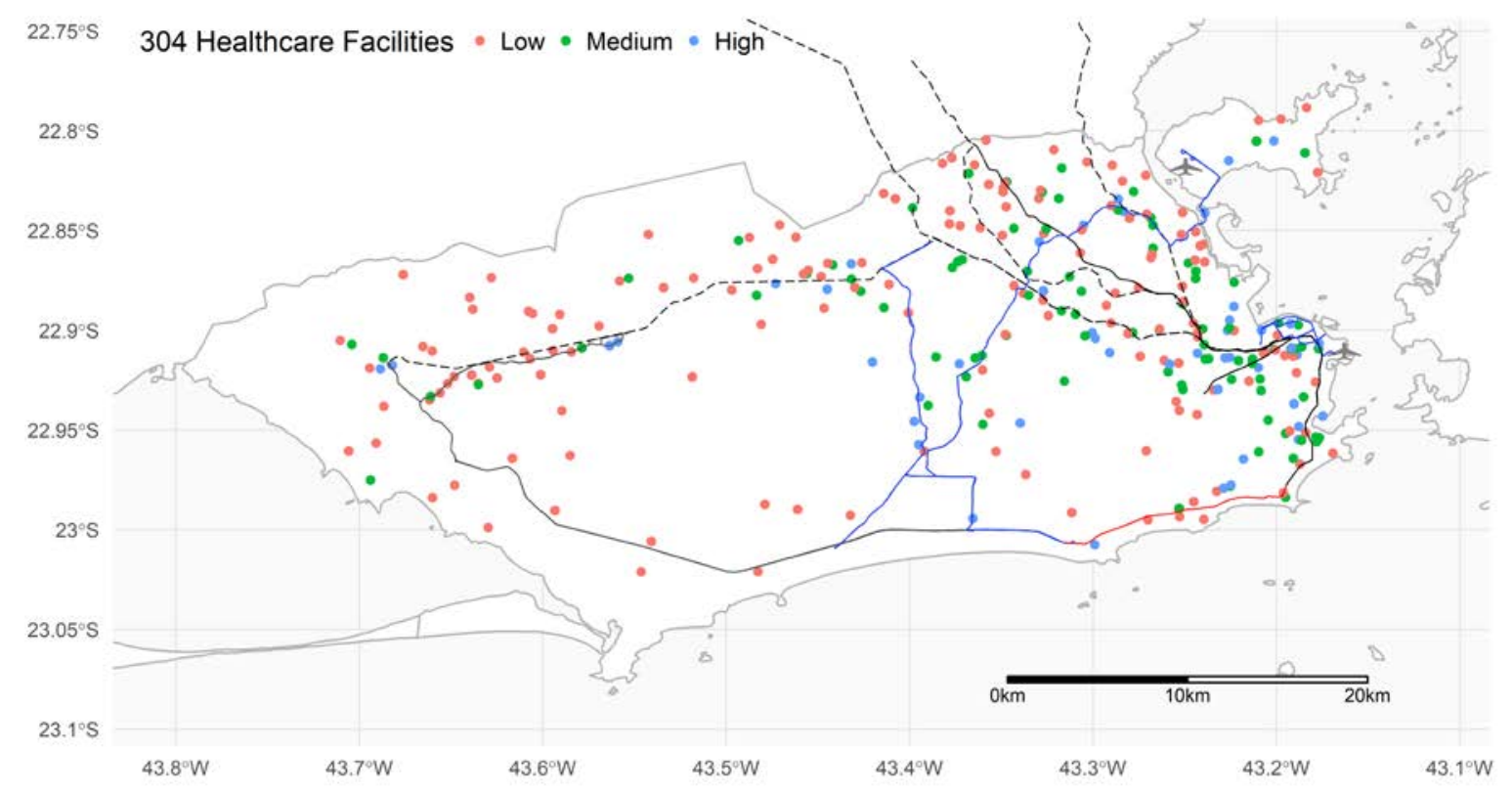

Spatial information on road networks and pedestrian infrastructure comes from OpenStreetMap, while data on Rio's public transport system comes from geolocated timetables from April 2014 and March 2017. These data are organized in General Transit Feed Specification (GTFS) format, bringing detailed geolocated information on routes, stops and timetables. An important caveat of the GTFS dataset is that it does not account for congestion levels and it may overestimate service performance in some areas and times of the day.

\subsection{Catchment size and composition}

The method used in this paper required three steps. In the first step, travel-time estimates between every pair of grid cells by public transport and walking were calculated using OpenTripPlanner (OTP), an open-source routing engine ${ }^{4}$. Several travel-time matrices were estimated departing every 20 minutes between 7 am and 7pm to account for fluctuations in service availability at

${ }^{4}$ https://github.com/opentripplanner/OpenTripPlanner 
various times of the day. These door-to-door estimates allow us to consider temporal variations in public transport services and to consider walking time from the point of origin to the transit stop, waiting time for the vehicle, actual travel time through the transport network and eventual transfers, and the walking time from the transit stop to the final destination.

The second step was to combine the travel-time matrices with the geolocated data on population, sports venues and healthcare facilities. Following the equation below, the size of the population by income within the catchment area of each location was calculated for a typical working day in April 2014 and March 2017 using time thresholds of 15, 30, 60 and 90 minutes. Multiple thresholds were used because there are no universal boundaries on acceptable travel times (insofar as they exist, there will likely be difficult-to-identify differences across and within income groups and by trip purpose). The specific values selected are commonly used in accessibility analysis involving cumulative opportunity measures (Boisjoly \& El-Geneidy, 2017). As an illustration, the catchment area of high-complexity healthcare facilities includes every person that could reach one of those facilities from their home by walking or public transport within a time threshold of, for example, 30 minutes.

$$
\begin{aligned}
& C_{d, i, T}=\operatorname{median}\left(\sum_{o=1}^{n} P_{i o} f\left(t_{o d r}\right)\right) \\
& f\left(t_{o d r}\right)=\left\{\begin{array}{l}
1 \text { if } t_{o d r} \leq T \\
0 \text { if } t_{o d r}>T
\end{array}\right.
\end{aligned}
$$

Where:

$\mathrm{C}_{\mathrm{d} \text { i } \mathrm{T}}$ is the catchment size of destination d for population of income i within time threshold $\mathrm{T}$. $\mathrm{P}_{\mathrm{i} \text { o }}$ is the number of people with income $\mathrm{i}$ in location o $\mathrm{t}_{\mathrm{od} \mathrm{r}}$ is the travel time in minutes between origin o and destination $\mathrm{d}$ at departure time $\mathrm{r}$. $f\left(t_{0} d r\right)$ is a time threshold function that varies between one and zero, depending on whether travel time $\left(\mathrm{t}_{\mathrm{o}} \mathrm{r}\right)$ is larger or smaller than time threshold $\mathrm{T}$.

In the final step, a before-and-after comparison of Rio’s transport system was conducted in which the spatial distribution of the population and its income distribution, sports venues and healthcare facilities are kept constant. This assumption allowed us to isolate the effect of the new transport investments on the variations in the catchment areas (size and income composition) between 2014 and 2017. The assumption disregards changes in the spatial distribution of socioeconomic groups and healthcare facilities that may have occurred over the period, but such changes 
tend to occur over timescales considerably exceeding those of the current analysis; changes during the 2014-2017 period are highly unlikely to have significantly affected the overall results of the current analysis.

Accessibility changes were also estimated under a quasi-counterfactual scenario in order to isolate what would have been the sole effect of the new transport investments. This scenario simulates as if all public transport services provided in April 2014 would have been kept constant, without any reorganization of regular bus lines or reduction in service levels. Thus, the only modifications to Rio's public transport system in this analysis were the addition of the new public transport infrastructure, i.e. the BRTs Transcarioca and Transolímpica and the new subway and light-rail lines.

A few limitations of this methods should be mentioned. First, travel-time estimates are based on information of service timetables. The misreporting of timetables and congestion levels could lead to overestimated accessibility levels. This shortcoming could be addressed by future studies by using GPS data of vehicles to generate more realistic travel-time estimates (Wessel et al., 2017). Secondly, the accessibility levels estimated in this study could be at least partially eroded by the cost of transport fares and by overcrowded and unsafe vehicles. Although these factors can significantly accessibility, these issues could not be incorporated into the analysis because of data constraints. Therefore, future research could benefit from a more nuanced understanding of accessibility as a personal attribute and thus incorporate the diversity in people's abilities to use the transport systems and move around the city; such research could include aspects of affordability, age, gender, disability, etc. This would also help draw attention to an underinvestigated question related to what extent transport investments driven by mega-events contribute to building a barrier-free urban environment and improve the mobility conditions of elderly and disabled people (Darcy, 2003).

\section{Results}

Figure 5 depicts, for each grid cell, the proportion of the city population that could reach it within 60 minutes by public transport and/or walking in 2014 and 2017. Brighter yellow colors indicate that the areas along high-capacity corridors are substantially more accessible than peripheral and 
less connected areas, particularly towards the northwest of Rio where a large share of the population lives. As an illustration, the Maracanã football stadium (\#7 in Figure 3) could be reached by approximately $48 \%$ of the city population within one hour by public transport/walking in the year 2017.

Figure 5. Proportion of the city population within the catchment area of 60 minutes by public transport and walking. Rio de Janeiro, 2014 and 2017.

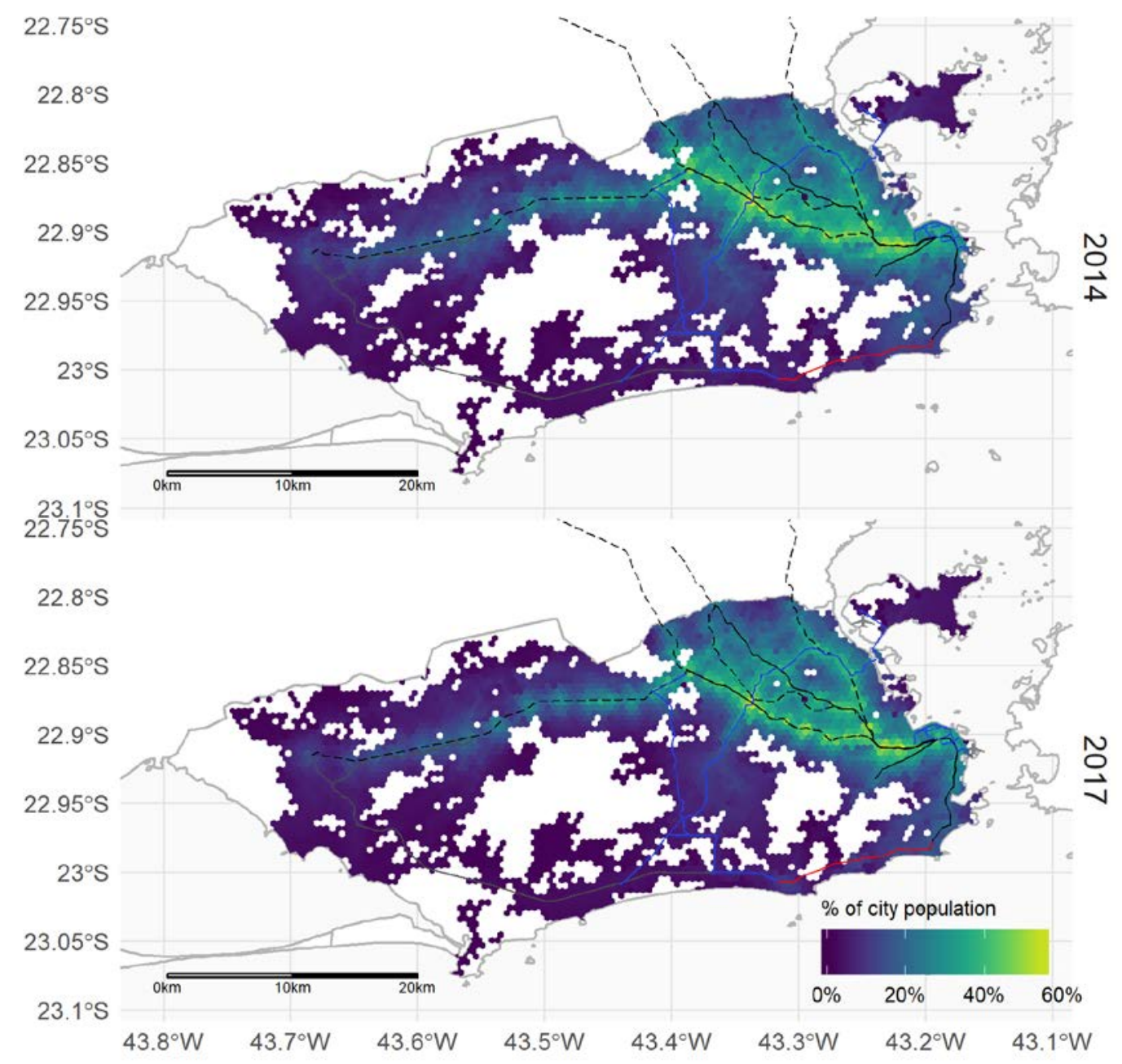

Figure 6 highlights how the size of catchment areas have changed in percentage points between 2014 and 2017 for both implemented and counterfactual scenarios. It shows how several areas in the city have become relatively less accessible to the population because of the streamlining of bus lines and reduction in service levels. One of the largest declines happened in 
between Realengo, Taquara and Oswaldo Cruz neighborhoods (clustered in dark orange). These neighborhoods were more intensely affected after two bus companies that operated in those areas went bankrupt (Borges, 2016; Zarur, 2017). Figure 6 also indicates that, in a quasi-counterfactual scenario where the new investments would have been implemented without the reorganization of bus lines, the new transport infrastructure would have mostly improved transport accessibility to those areas which were already relatively better connected via the subway and train systems. The analysis of catchment areas within 30, 60 and 90 minutes shows that those investments would not have improved access to peripheral areas.

Figure 6. Variation in percentage points of the city population within the catchment area of 60 minutes by public transport and walking in implemented and counterfactual scenarios. Rio de Janeiro, 2014 and 2017

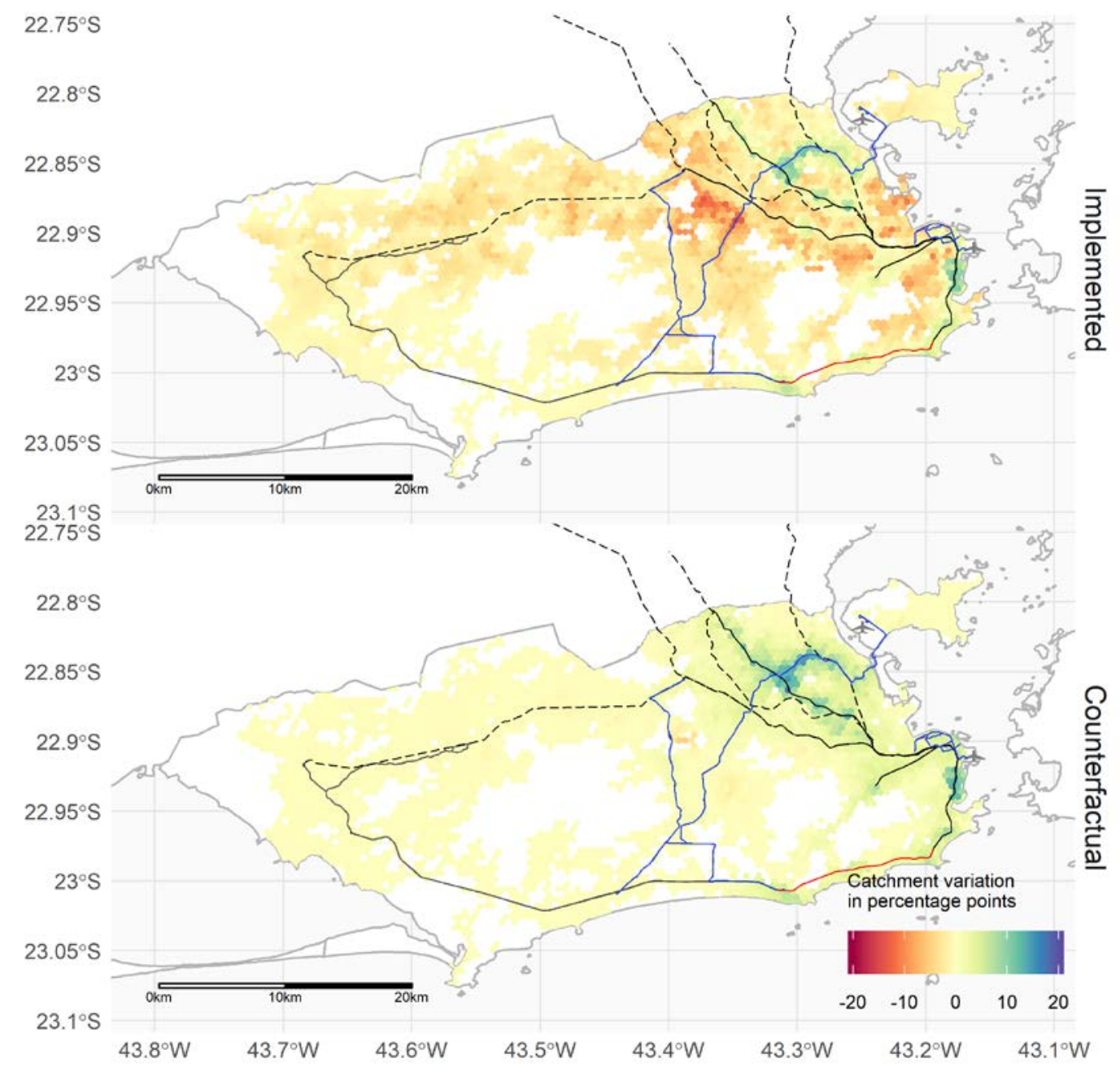




\subsection{Sports venues}

Focusing more specifically on how recent transport policies have changed the population's access to Olympic Sports venues, Figures 7 and 8 show how the size and the income composition of the population within the catchment areas of those facilities have changed between 2014 and 2017, including the results for the quasi-counterfactual scenario. There is a marked variation in the size of catchment areas, reflecting how the sports venues are dispersed across the city. Venues such as the Olympic park are located in less densely populated and less connected areas, while the Olympic Stadium is located in a much denser and better connected area. This figure also shows how the income composition of the catchment areas of Olympic sports venues is also quite varied, although higher-income groups are generally overrepresented in the catchment areas of almost every sports venue. In the most extreme cases, over $75 \%$ of the population that could reach the sports venues of the Lagoa Stadium and the Golf Court under one hour by public transport and walking belong to the two richest income deciles.

Figure 7. Population size and income composition within the catchment area of 60 minutes by public transport and walking of Olympic Sports Venues. Rio de Janeiro, 2014-2017.

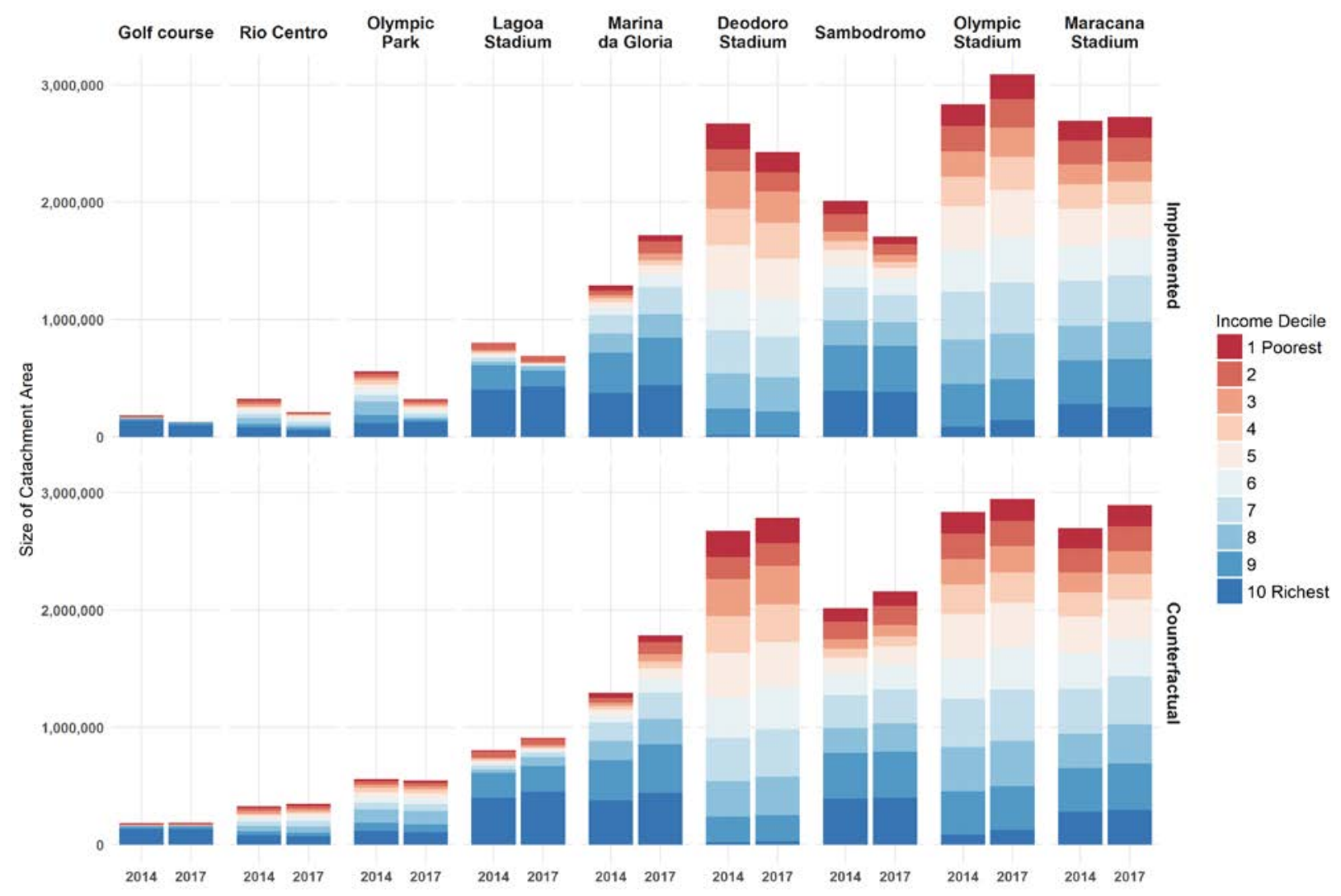


Figure 8 suggests that the reorganization of bus services and cuts in service levels have generally offset the new transport investments in Rio. It shows how, on the whole, the policies implemented in the city have reduced catchment size of every sports venue, with the exception of Marina da Gloria and the Olympic and Maracanã Stadiums. While the quasi-counterfactual scenario shows that the transport infrastructure expansion alone would have increased the number of people who could access every venue, the results from both scenarios indicate that the accessibility benefits generally accrued to middle- and higher-income groups, leading to an increase in accessibility inequality across income groups.

Figure 8. Variation in the population size (by income groups) of the catchment areas of 60 minutes by public transport and walking of Olympic Sports Venues between 2014 and 2017. Rio de Janeiro.

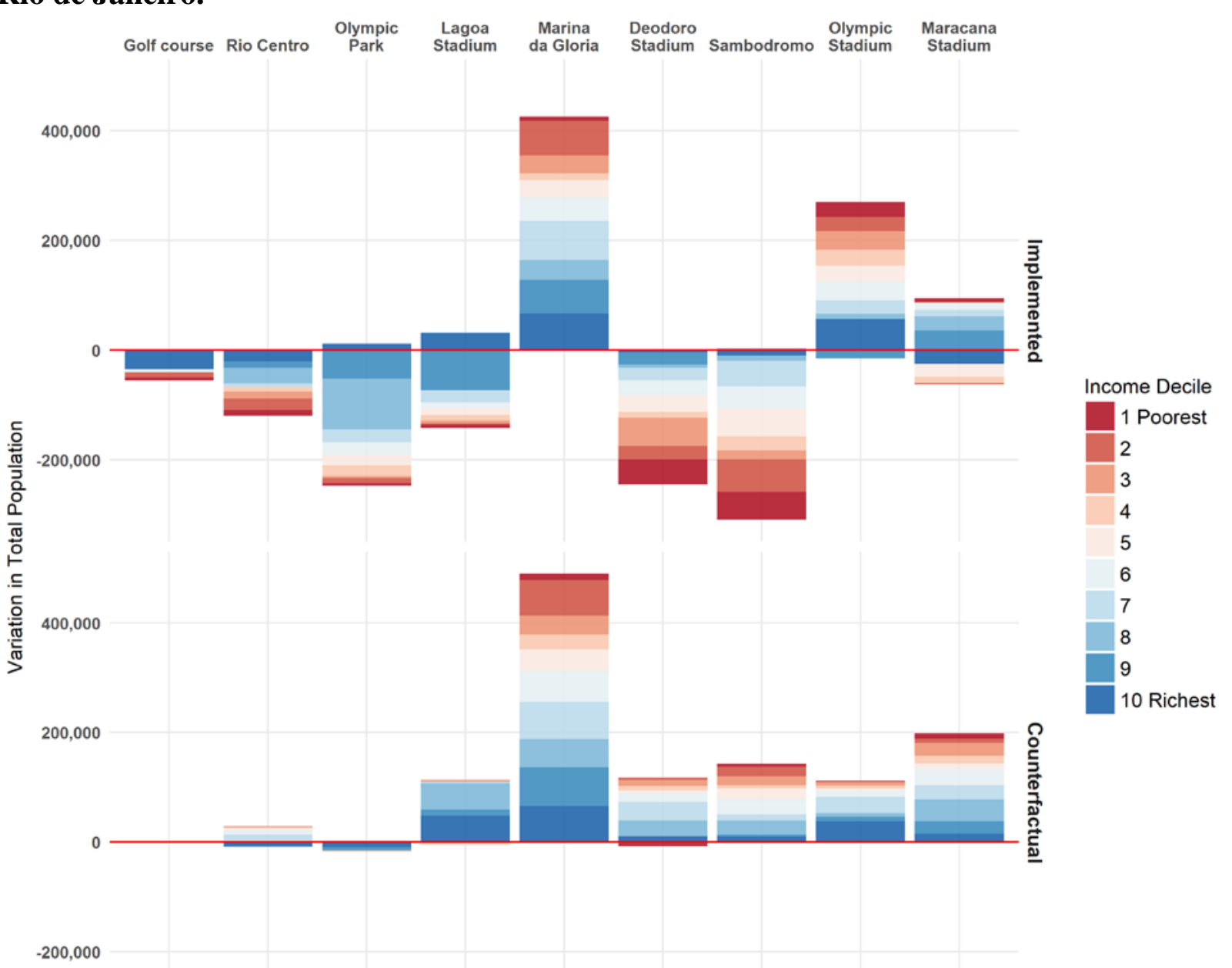


Two conclusions follow from the above. These results indicate that the potential benefits of new transport infrastructure were to a large extent offset by the subsequent reorganization of service levels, leading to a general decrease in the population's access to the Olympic sports venues. Moreover, both the changes implemented to the transport system the new investments alone fail to meet the second Rawlsian criterion of justice because they have been unable to improve the accessibility of low-income groups, which still have lower transport access to the facilities compared to middle- and high-income groups. This is also in part because most of the sports venues are located either in high-income areas which were already relatively more accessible (such as Marina da Gloria and Lagoa Stadium), or in lower-income lower-density areas that remained poorly connected to the rest of the city (such as Rio Centro and Olympic Park). Although the paper only presents figures under a time-threshold of 60 minutes due to lack of space, these general conclusions also hold under thresholds of 30 and 90 minutes.

\subsection{Healthcare facilities}

Given the interest in analyzing the legacy of recent transport developments in Rio, it is also particularly important to understand the extent to which this cycle of investments and disinvestment have impacted people's access to essential services such as healthcare. Given a 60minute travel time threshold, close to $95 \%$ of the city population could reach a healthcare facility at any level of service complexity either before or after the investments. However, the conclusions change when a 30-minute threshold is used. This threshold is not only commonly used in other studies of accessibility to healthcare (Neutens, 2015) but also seems to be a more realistic value for people whose physical mobility is likely to be hindered in various ways.

Figures 9 and 10 show the how the size and the income composition of the population within a 30-minute catchment area of healthcare facilities has changed between 2014 and 2017 and how it would have changed in the quasi-counterfactual scenario. In the year 2017, approximately 5.8 million people, the equivalent of $94.5 \%$ of Rio's population, could reach at least one of the 224 facilities providing low complexity services via public transport and walking under 30 minutes. For the 93 medium-complexity and the 94 high-complexity facilities, these figures 
were approximately 5 and 4.4 million people $-81 \%$ and $73 \%$ of the city population, respectively. Furthermore, the distribution across income classes was roughly even but less so for services of high level of complexity, which were more accessible to wealthier groups. ${ }^{5}$

These relatively high levels of accessibility can, to some extent, be explained by the spatial planning of healthcare facilities in the region (Rio de Janeiro, 2014), which has been relatively successful in redistributing low- and medium-complexity healthcare facilities equally across the city of Rio. Because those healthcare facilities are fairly distributed across the city, even significant modifications in the transport systems as the ones observed in Rio would lead to relatively small changes to the catchment areas of those facilities.

\section{Figure 9. Population size and income composition within a 30 min catchment area of healthcare facilities by service complexity. Rio de Janeiro, 2014-2017.}

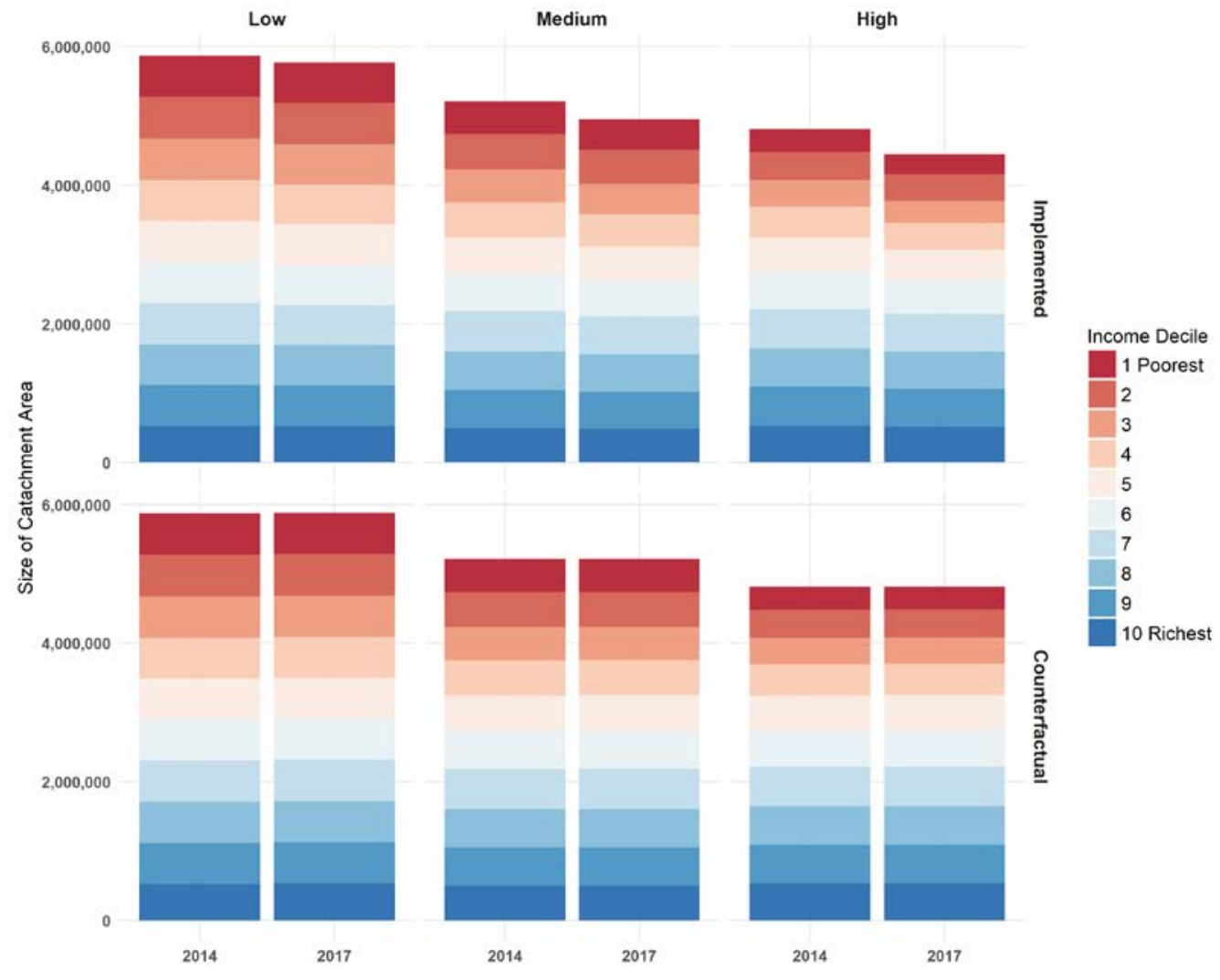

\footnotetext{
${ }^{5}$ It is worth noting, however, that healthcare facilities at the same level of complexity are not all interchangeable because they do not necessarily provide the same services. This paper could thus be complemented by future studies providing detailed analyses of people's accessibility to particular types of treatment that demand more frequent trips to the hospital, such as hemodialysis, physical rehabilitation, etc.
} 
The quasi-counterfactual analysis suggests that the new investments alone would have had only a marginally positive effect, increasing by a few thousands the number of people who could reach healthcare facilities. In contrast, what was observed is that the total catchment areas of low, medium- and high-complexity facilities have shrunk respectively by $1.6 \%, 4.9 \%$ and $7.5 \%$ between 2014 and 2017 (Figure 9). This reduction has resulted from the reorganization of the bus routes and particularly from a reduction in service frequency in some parts of the system, which have given rise to many complaints from users (Magalhães \& Rodrigues, 2017; O Globo, 2016; M. Rodrigues, 2016). Given a travel time budget of, for example, 30 minutes, lowering service frequency not only reduces people's choice of departure time but also is more likely to extend their waiting time at bus stops at the expense of travel time inside the vehicle, thus reducing the distances covered and the area that is accessible. The detrimental effect of the streamlining of the bus systems was not identified with the same intensity when considering a travel time threshold of 60 minutes. This is because the headway effect on the size of the catchment area will be smaller as the travel time budget gets larger and the waiting time at a transit stop represents a smaller share of total travel time (Ratio between waiting time and travel time).

Furthermore, Figure 10 suggest that the reduction in service levels have not affected all income classes in the same way. The combination of new infrastructure investments and reorganization of the bus routes have made medium- and high-complexity healthcare facilities more accessible to higher-income groups while at the same time reducing their accessibility to the poor. These analyses were also conducted considering a 15-minute threshold. This resulted in even higher levels of inequality between higher- and lower-income groups in terms of their access to healthcare facilities of medium and high complexity. This is largely because most of these facilities are located in relatively wealthier regions of the city. 
Figure 10. Variation in the population size (by income) within a 30 min catchment area of healthcare facilities (by service complexity) between 2014 and 2017. Rio de Janeiro.

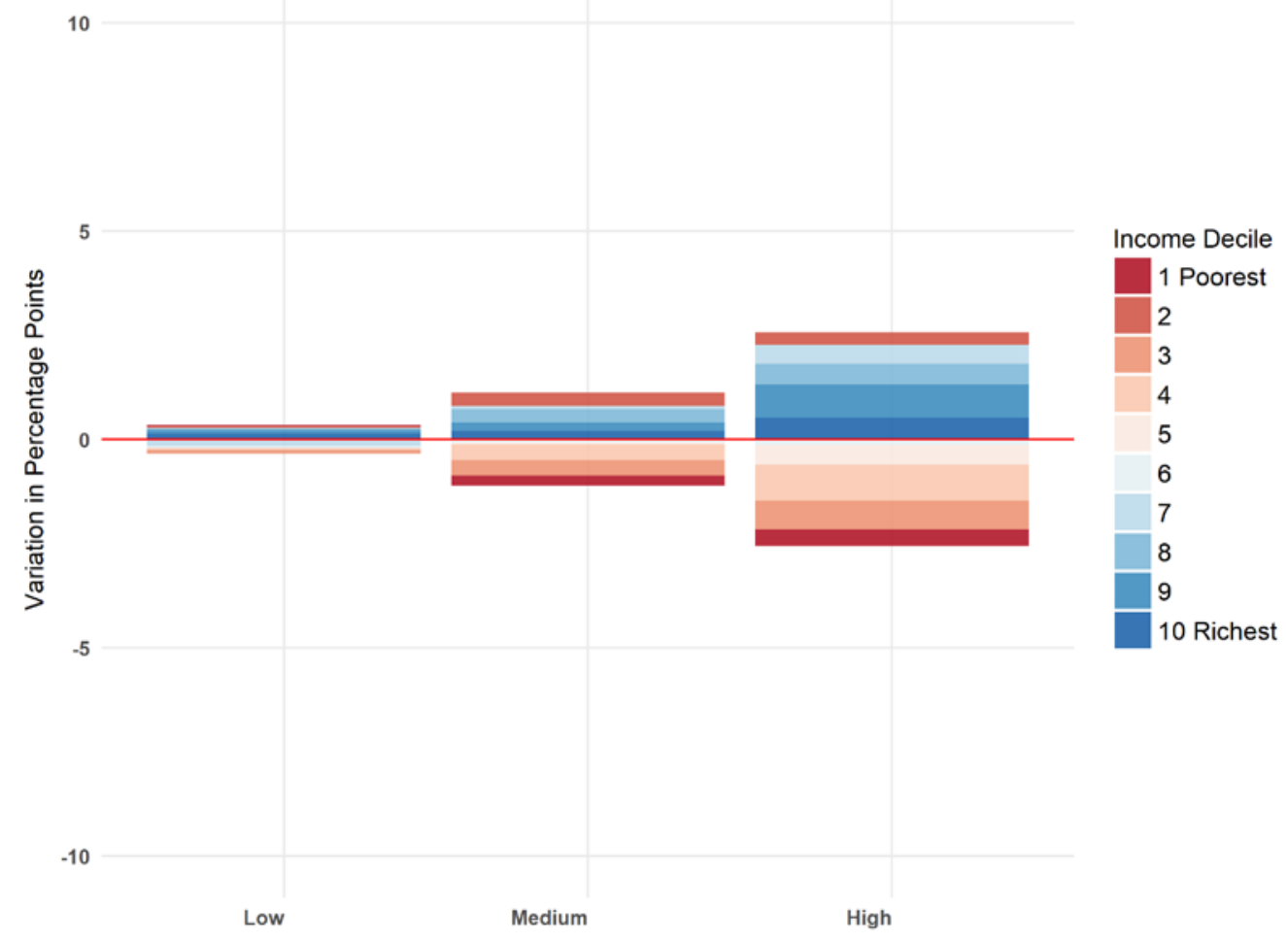

In summary, independent of income level, the population of Rio already had relatively high levels of accessibility to healthcare facilities. This is largely due to the policy-led spatial distribution of such facilities across the city, and hence the recent cycle of investments and disinvestments had only a minor effect on people’s access to such facilities. The newly added transport infrastructure alone would only have marginally improved accessibility levels. In contrast, the new investments combined with the reorganization of the city's public transport system has actually reduced accessibility levels to medium- and high-complexity healthcare facilities, particularly for lower-income groups, and this outcome contradicts Rawls' second principle of justice. This result shows how the streamlined bus system have to some extent offset the benefits of additional transport infrastructure in a way that particularly penalizes the poor. 


\subsection{Final remarks}

This paper has sought to contribute to discussions of transport planning in the context of megaevents and of how transport legacies can help shape socio-spatial inequalities by reconfiguring urban accessibility to opportunities. Previous research has documented various issues associated with the hosting of sports mega-events in general and in Rio in particular. The lack of participatory policy and the violation of the social rights of local communities have been particularly discussed in previous studies about Rio de Janeiro (Faulhaber \& Nacif, 2013; Gaffney, 2016; Santos, 2013). This paper complements previous research by evaluating how event-led investments in Rio and its subsequent transport policies have affected the daily transport conditions of local residents after the events, particularly investigating whether alleged transport legacies had an effect of equalizing access to opportunities.

Overall, the results indicate that the new investments in Rio's transport system have not, despite the promise in Rio's Olympic bid file, radically improved transport conditions of poor people living in the peripheries of the city (BOC, 2009; Brazil, 2009; Rio de Janeiro, 2008). A quasi-counterfactual analysis suggests that the new infrastructure expansion alone would have increased the number of people who could access the Olympic sports venues, but they would only marginally improve people's access to healthcare facilities. Nonetheless, a before-and-after comparison of Rio's public transport system shows that the subsequent reorganization of bus routes and reductions in service levels have generally offset the potential accessibility benefits of the newly added transport infrastructure in a way that particularly penalizes the poor. Except for Marina da Gloria, the Olympic and Maracanã stadiums, all Olympic sports venues have become less accessible to the population via public transport and walking. Similarly, the catchment areas of healthcare facilities in all levels of service complexity have shrunk between $1.6 \%$, and $7.5 \%$ from 2014 to 2017. Moreover, this cycle of investments and disinvestments in Rio de Janeiro's public transport system have not been able to reduce the accessibility gap between higher- and lower-income groups. The analysis of both implemented and quasi-counterfactual scenarios shows that the accessibility benefits from the transport policies implemented in Rio generally accrued to middle- and higher-income groups, reinforcing existing patterns of urban inequality. 
To some extent, this is because the expansion of transport infrastructure was mostly concentrated in areas of the city that were already relatively accessible to a large part of the population, while the subsequent streamlining and reduction of bus services have mostly affected lower-income areas. This market-driven reorganization of the bus lines to accommodate the new investments did not follow a redistributive justice logic. It has actually hurt low-income groups and exacerbated inequality between wealthier and poorer populations in terms of access to medium and high-complexity health services. In different ways, it is possible to say that the Transport legacy of mega-events in Rio was not immune to mega-event syndrome discussed by Müller (2015). This is consistent with other urban planning regimes in Rio that, since its strategic plan in the late 1990s, have generally privileged urban development policies in wealthier areas of the city at the expense of poorer communities (Gaffney, 2015; Ribeiro et al., 2010; Santos, 2013).

These results draw attention to the question of what would be the appropriate time and geographical scales with which to define the legacy of mega-events and of other forms of infrastructure development more broadly. As the analysis of the transport legacy in Rio illustrates, the conclusions of a project impact assessment can be significantly different depending on the way one delimits the boundary of what counts as part of a project legacy. The impact of the transport legacy of megaevents in Rio, for example, change from positive to negative depending on whether one uses a narrow understanding of legacy that only includes the recent expansion in transport infrastructure or a broader view that also incorporates the subsequent policies adopted to accommodate those investments and to cope with the economic crisis. Moreover, in the case of Rio de Janeiro, the analysis in this paper had to focus on the city scale because of data limitations. A study conducted at the metropolitan scale would likely find much higher levels of inequality in access to opportunities, as Rio's urban periphery has relatively poorer population, lower availability of public services and transport services that have not directly benefited from the transport investments related to mega-events (Castro et al., 2015; Ribeiro, 2014). Ultimately, there is a profoundly political and normative dimension to the question of how the legacy of infrastructure development projects are defined.

It is unrealistic to expect that new transport investments can bring equal benefits to every neighborhood in a city. From a social justice point of view, however, a Rawlsian approach would expect that transport policies would respect individuals' rights and improve the transport 
conditions of people in the worst situations, helping reduce inequality of access to opportunities (Pereira et al., 2017). Nonetheless, what was observed is that the transport legacy of Rio’s megaevents violated both of Rawls' principles of justice, as these investments have been associated with the violation of housing rights of local communities and have brought little improvement to the transport conditions of the poor. In fact, the changes made to the city's transport system have exacerbated socio-spatial inequalities by reducing the ability of the population, particularly of lowincome transit-dependent groups, to access medium and high-complexity healthcare facilities.

This paper has only focused on the short-term impacts of transport legacy in terms of its effects on people’s transport accessibility via public transport. The construction of Rio’s BRTs has involved major road-widening, which is likely to improve accessibility of car users and thus exacerbate even further accessibility inequalities between the rich and the poor. Moreover, a broader view of transport legacy would be necessary to investigate other ways in which transport projects influence urban development, such as the reorganization of economic actives in urban space, reduction of traffic accidents and transport emissions, and impacts on land values. A report by the Rio city government (Rio de Janeiro, 2015), for example, indicates that some neighborhoods served by BRT Transcarioca have already observed a sharp increase in real estate prices between 2012 and 2015, which could lead to affordability issues and offset the eventual accessibility benefits received by low income families (Gaffney, 2016). Therefore, it is not entirely clear how the impact of the transport legacy in Rio will evolve over time and whether it will adequately correspond to future changes in the mobility needs of the population. However, even in cases where one could argue that these investments involve short-term pain that will be compensated by longer-term gains, from a Rawlsian perspective, these long-term benefits would not justify the rights violations that have been observed in Rio.

Two other broad lessons can be drawn from the study of the transport legacy of megaevents in Rio de Janeiro. One is that the case of Rio exemplifies how the apparent alignment of mega-event-related investments with long-term city plans is not a sufficient condition to create a positive legacy for local communities. The case of Rio illustrates how local governments can incorporate the realization of mega-events into their long-term strategies to promote urban development (Silvestre, 2012) and at the same time adapt existing transport projects in favor of the short-term needs of the events (Kassens-Noor et al., 2016; Santos, 2013). Moreover, new 
transport investments are often followed by reorganization of services to accommodate newly added infrastructure and these factors are often neglected in discussions around the impacts of new transport projects. In the case of Rio, this has been aggravated by an economic recession and fiscal crisis that have undermined the transport legacy of recent mega-events.

Finally, this evaluation of Rio's transport legacy illustrates how the legacy of mega-events can have inequitable impacts in host cities and exacerbate socio-spatial inequalities in access to opportunities, making a strong case that the debate about the impacts of urban infrastructure projects must move beyond a net-sum analysis. The evaluation of mega-events' impacts and transport legacies cannot be disconnected from a critical analysis of who benefits from such investments, as well as where and how these benefits are realized.

\section{Acknowledgements}

The author would like to thank a reviewer for useful and constructive comments. The author would like to thank David Banister and Tim Schwanen for their thoughtful comments on previous versions of this paper. This work was supported by Capes Foundation, Ministry of Education, Brazil [Grant Number BEX 1397/13-3], the Brazilian Institute for Applied Economic Research (Ipea) and the Lee Schipper Memorial Scholarship. 


\section{References}

Andranovich, G., \& Burbank, M. J. (2011). Contextualizing Olympic Legacies. Urban Geography, 32(6), 823-844. doi:10.2747/0272-3638.32.6.823

Andranovich, G., Burbank, M. J., \& Heying, C. H. (2001). Olympic Cities: Lessons Learned from Mega-Event Politics. Journal of Urban Affairs, 23(2), 113-131. doi:10.1111/07352166.00079

Armstrong, G., Hobbs, D., \& Lindsay, I. (2011). Calling the Shots The Pre-2012 London Olympic Contest. Urban Studies, 48(15), 3169-3184. doi:10.1177/0042098011422397

Baade, R. A. (1996). Professional Sports as Catalysts for Metropolitan Economic Development. Journal of Urban Affairs, 18(1), 1-17. doi:10.1111/j.1467-9906.1996.tb00361.x

Baade, R. A., \& Matheson, V. A. (2004). The Quest for the Cup: Assessing the Economic Impact of the World Cup. Regional Studies, 38(4), 343-354. doi:10.1080/03434002000213888

Banister, D. (2002). Transport Planning (2 edition.). London u.a.: Spon: Routledge.

Basta, C. (2015). From justice in planning toward planning for justice: A capability approach. Planning Theory, 1473095215571399. doi:10.1177/1473095215571399

BOC. (2009). Rio de Janeiro's Candidature File to host the 2016 Olympic and Paralympic Games (No. 1, 2 and 3). Brazilian Olympic Committee. Retrieved from http://www.rio2016.com/en/organising-committee/transparency/documents

Boisjoly, G., \& El-Geneidy, A. M. (2017). How to get there? A critical assessment of accessibility objectives and indicators in metropolitan transportation plans. Transport Policy, 55, 3850. doi:10.1016/j.tranpol.2016.12.011

Borges, B. (2016, December 5). Auto Viação Bangu decreta falência no Rio. Retrieved October 5, 2017, from http://noticias.band.uol.com.br/cidades/rio/noticias/100000806203/autoviacao-bangu-decreta-falencia-apos-semana-turbulenta

Brazil. (2007). Assistência de Média e Alta Complexidade no SUS (No. 9). Brasília: Conselho Nacional de Secretários de Saúde. Retrieved from http://bvsms.saude.gov.br/bvs/publicacoes/colec_progestores_livro9.pdf

Brazil, S. M. (2009). Caderno de Legados Urbano e Ambiental. Rio 2016 Cidade Candidata. Sport Ministry.

Retrieved

from http://www.esporte.gov.br/arquivos/rio2016/cadernoLegadosUrbanoAmbiental.pdf

Broudehoux, A.-M. (2007). Spectacular Beijing: The Conspicuous Construction of an Olympic Metropolis. Journal of Urban Affairs, 29(4), 383-399. doi:10.1111/j.14679906.2007.00352.x

Brownill, S., Keivani, R., \& Pereira, G. (2013). Olympic legacies and city development strategies in London and Rio; beyond the carnival mask? International Journal of Urban Sustainable Development, 5(2), 111-131. doi:10.1080/19463138.2013.840637 
Burbank, M. J., Andranovich, G., \& Heying, C. H. (2002). Mega-Events, Urban Development, and Public Policy. Review of Policy Research, 19(3), 179-202. doi:10.1111/j.15411338.2002.tb00301.x

Castro, D. G., Gaffney, C., Novaes, P. R., ... Santos Junior, O. A. dos (Eds.). (2015). Rio de Janeiro: os impactos da Copa do Mundo 2014 e das Olimpíadas 2016 (1st ed.). Rio de Janeiro: Letra Capital,.

Cervero, R. B. (2013). Linking urban transport and land use in developing countries. Journal of Transport and Land Use, 6(1), 7-24. doi:10.5198/jtlu.v6i1.425

Chalkley, B., \& Essex, S. (1999). Urban development through hosting international events: a history of the Olympic Games. Planning Perspectives, 14(4), 369-394. doi:10.1080/026654399364184

Chappelet, J.-L. (2012). Mega Sporting Event Legacies: A Multifaceted Concept. Papeles de Europa, 0(25), 76-86. doi:10.5209/rev_PADE.2012.n25.41096

Chappelet, J.-L., \& Junod, T. (2006). A tale of 3 Olympic cities: What can Turin learn from the Olympic legacy of other Alpine cities. Major Sport Events as Opportunity for Development. Valencia: Valencia Summit Proceedings.

Collins, A., Flynn, A., Munday, M., \& Roberts, A. (2007). Assessing the Environmental Consequences of Major Sporting Events: The 2003/04 FA Cup Final. Urban Studies, 44(3), 457-476. doi:10.1080/00420980601131878

Collins, A., Jones, C., \& Munday, M. (2009). Assessing the environmental impacts of mega sporting events: Two options? Tourism Management, 30(6), 828-837. doi:10.1016/j.tourman.2008.12.006

Cornelissen, S., Bob, U., \& Swart, K. (2011). Towards redefining the concept of legacy in relation to sport mega-events: Insights from the 2010 FIFA World Cup. Development Southern Africa, 28(3), 307-318. doi:10.1080/0376835X.2011.595990

Costa, M. A., Santos, M. A., Rahy, I. S., ... Silva, L. F. F. T. da. (2015). Caracterização e Quadros de Análise Comparativa da Governança Metropolitana no Brasil: análise comparativa das funções públicas de interesse comum (Componente 2) - RM do Rio de Janeiro (Relatório de Pesquisa). Rio de Janeiro: Institute for Applied Economic Research - Ipea. Retrieved from http://www.ipea.gov.br/portal/index.php?option=com_content\&view=article\&id=26361

CPCORJ. (2015). Rio 2016 Olympics: The Exclusion Games - Mega-Events and Human Rights Violations in Rio de Janeiro Dossier. Rio de Janeiro: Comitê popular Copa e Olimpíadas Rio - World Cup and Olympics Popular Committee of Rio de Janeiro. Retrieved from https://comitepo pulario.files.wordpress.com/2016/03/dossiecomiterio2015_eng1.pdf

Cuadros, A. (2016, August 1). The Broken Promise of the Rio Olympics. The Atlantic. Retrieved from http://www.theatlantic.com/international/archive/2016/08/building-barra-rioolympics-brazil/493697/

Currie, G., \& Shalaby, A. (2012). Synthesis of Transport Planning Approaches for the World's Largest Events. Transport Reviews, 32(1), 113-136. doi:10.1080/01441647.2011.601352 
Darcy, S. (2003). The politics of disability and access: the Sydney 2000 Games experience. Disability \& Society, 18(6), 737-757. doi:10.1080/0968759032000119497

Death, C. (2011). “Greening” the 2010 FIFA World Cup: Environmental Sustainability and the Mega-Event in South Africa. Journal of Environmental Policy \& Planning, 13(2), 99-117. doi:10.1080/1523908X.2011.572656

Essex, S., \& Chalkley, B. (2004). Mega-sporting events in urban and regional policy: a history of the Winter Olympics. Planning Perspectives, 19(2), 201-204. doi:10.1080/0266543042000192475

Fainstein, S. S. (2010). The just city. Ithaca: Cornell University Press.

Faulhaber, L., \& Nacif, C. L. (2013). Rio Maravilha: desapropriações, remoções e reforço do padrão de organização espacial centro-periferia. Anais: Encontros Nacionais da ANPUR, 15(0). $\quad$ Retrieved from http://unuhospedagem.com.br/revista/rbeur/index.php/anais/article/view/4222

Flyvbjerg, B., \& Stewart, A. (2012). Olympic Proportions: Cost and Cost Overrun at the Olympics 1960-2012 (SSRN Scholarly Paper No. ID 2238053). Rochester, NY: Social Science Research Network. Retrieved from http://papers.ssrn.com/abstract=2238053

Fonseca, P. (2017, August 3). Brazil police arrest ex-Rio infrastructure head in Olympics graft probe. Reuters. Retrieved from https://www.reuters.com/article/us-brazil-corruptionolympics-idUSKBN1AJ2NY

França, R. (2016, December 11). Ônibus perdem passageiros durante a crise. O Globo. Retrieved from https://oglobo.globo.com/rio/onibus-perdem-passageiros-durante-crise-20625497

G1. (2017, February 6). Confira as novas mudanças de linhas de ônibus no Rio. Retrieved January 15, 2017, from http:/g1.globo.com/rio-de-janeiro/noticia/2016/02/confira-novasmudancas-de-linhas-de-onibus-no-rio.html

Gaffney, C. (2010). Mega-events and socio-spatial dynamics in Rio de Janeiro, 1919-2016. Journal of Latin American Geography, 9(1), 7-29. doi:10.1353/lag.0.0068

Gaffney, C. (2013). Between Discourse and Reality: The Un-Sustainability of Mega-Event Planning. Sustainability, 5(9), 3926-3940. doi:10.3390/su5093926

Gaffney, C. (2016). Gentrifications in pre-Olympic Rio de Janeiro. Urban Geography, 37(8), 1132-1153. doi:10.1080/02723638.2015.1096115

Gaffney, C. T. (2015). The mega-event city as neo-liberal laboratory: the case of Rio de Janeiro. Percurso Acadêmico, 0(0), 217-237.

Gold, J. R., \& Gold, M. M. (2008). Olympic Cities: Regeneration, City Rebranding and Changing Urban Agendas. Geography Compass, 2(1), 300-318. doi:10.1111/j.17498198.2007.00080.x

Gold, J. R., \& Gold, M. M. (2011). Olympic cities : city agendas, planning and the world's games, 1896-2016 (2nd ed.). London: Routledge.

Gratton, C., \& Preuss, H. (2008). Maximizing Olympic Impacts by Building Up Legacies. The International Journal of the History of Sport, 25(14), 1922-1938. doi:10.1080/09523360802439023 
Gratton, C., Shibli, S., \& Coleman, R. (2005). Sport and Economic Regeneration in Cities. Urban Studies, 42(5-6), 985-999. doi:10.1080/00420980500107045

Hensher, D. A., \& Brewer, A. M. (2002). Going for gold at the Sydney Olympics: How did transport perform? Transport Reviews, 22(4), 381-399. doi:10.1080/01441640110121112

Herdy, F. H. (2012). Dos planos urbanísticos ao projeto Rio 2016: a mobilidade urbana nas leituras de cidade. Universidade Federal Fluminense, Niterou.

Hiller, H. H. (2000a). Mega-events, Urban Boosterism and Growth Strategies: An Analysis of the Objectives and Legitimations of the Cape Town 2004 Olympic Bid. International Journal of Urban and Regional Research, 24(2), 449-458. doi:10.1111/1468-2427.00256

Hiller, H. H. (2000b). Mega-events, Urban Boosterism and Growth Strategies: An Analysis of the Objectives and Legitimations of the Cape Town 2004 Olympic Bid. International Journal of Urban and Regional Research, 24(2), 449-458. doi:10.1111/1468-2427.00256

Hiller, H. H. (2006). Post-event Outcomes and the Post-modern Turn: The Olympics and Urban Transformations. European Sport Management Quarterly, 6(4), 317-332. doi:10.1080/16184740601154458

Horne, J., \& Manzenreiter, W. (2006). An introduction to the sociology of sports mega-events. The Sociological Review, 54, 1-24. doi:10.1111/j.1467-954X.2006.00650.x

Hughes, C., \& Leshner. (2013). Impact Analysis of Transoeste Bus Rapid Transit System in Rio de Janeiro. Rio de Janeiro: ITDP Brasil.

IBGE. (2016). Grade Estatística 2010. Retrieved from http://mapas.ibge.gov.br/interativos/grade.html

Ipea. (2016). ipeadata. Retrieved from http://www.ipeadata.gov.br/

Ipea, UNPD, \& FJP. (2015). Atlas do desenvolvimento humano nas regiões metropolitanas brasileiras. Retrieved November 20, 2015, from http://www.atlasbrasil.org.br/

ITDP Brasil. (2013). Workshop de Planejamento Urbano no entorno da estação do BRT Transbrasil em Bonsucesso. Rio de Janeiro: ITDP Brasil.

ITDP Brasil. (2014). Análise do Fluxo de Pedestres nas Estações do BRT Transbrasil. Rio de Janeiro: ITDP Brasil. Retrieved from http://itdpbrasil.org.br/wpcontent/uploads/2014/11/Pedestrian-Flow-Analysis-Transbrasil_FINAL.pdf

ITDP Brasil. (2015). Análise de Impacto do BRT TransCarioca na Mobilidade Urbana do Rio de Janeiro. Rio de Janeiro: ITDP Brasil. Retrieved from https://www.itdp.org/wpcontent/uploads/2015/04/ITDP-Brasil_An\%C3\%A1lise-Impacto-BRT-TransCarioca_emPT_vers\%C3\%A3o-WEB-para-site.pdf

Jones, C. (2001). A level playing field? Sports stadium infrastructure and urban development in the United Kingdom. Environment and Planning A, 33(5), 845 - 861. doi:10.1068/a33158

Kasimati, E. (2003). Economic aspects and the Summer Olympics: a review of related research. International Journal of Tourism Research, 5(6), 433-444. doi:10.1002/jtr.449

Kassens-Noor, E. (2010). Sustaining the Momentum. Transportation Research Record: Journal of the Transportation Research Board, 2187, 106-113. doi:10.3141/2187-14 
Kassens-Noor, E. (2012). Planning Olympic Legacies: Transport Dreams and Urban Realities. Routledge.

Kassens-Noor, E. (2013). Transport Legacy of the Olympic Games, 1992-2012. Journal of Urban Affairs, 35(4), 393-416. doi:10.1111/j.1467-9906.2012.00626.x

Kassens-Noor, E., Gaffney, C., Messina, J., \& Phillips, E. (2016). Olympic Transport Legacies: Rio de Janeiro's Bus Rapid Transit System. Journal of Planning Education and Research, 0739456X16683228. doi:10.1177/0739456X16683228

Kommenda, N. (2016, August 2). How evictions have laid bare Rio’s real Olympic legacy. The Guardian. Retrieved from http://www.theguardian.com/sport/nginteractive/2016/aug/02/how-evictions-have-laid-bare-rios-real-olympic-legacy

Legroux, J. (2014). From discourse to reality: impacts of Rio's "transportation revolution" on socio-spatial justice. In L. C. de Q. Ribeiro, The Metropolis of Rio de Janeiro: a space in transition (1st ed., pp. 343-372). Rio de Janeiro: Letra Capital.

Leopkey, B., \& Parent, M. M. (2012). Olympic Games Legacy: From General Benefits to Sustainable Long-Term Legacy. The International Journal of the History of Sport, 29(6), 924-943. doi:10.1080/09523367.2011.623006

Liu, M., Mao, B., Huang, Y., ... Chen, S. (2008). Comparison of Pre- \& Post-Olympic Traffic: A Case Study of Several Roads in Beijing. Journal of Transportation Systems Engineering and Information Technology, 8(6), 67-72. doi:10.1016/S1570-6672(09)60006-4

Lucas, K. (2012). Transport and social exclusion: Where are we now? Transport Policy, 20, 105113. doi:10.1016/j.tranpol.2012.01.013

Lucas, K., Wee, B. van, \& Maat, K. (2015). A method to evaluate equitable accessibility: combining ethical theories and accessibility-based approaches. Transportation, 1-18. doi:10.1007/s11116-015-9585-2

Magalhães, L. E., \& Rodrigues, R. (2017, June 6). Sistema BRT completa 5 anos sem motivos para comemorar. O Globo. Retrieved from https://oglobo.globo.com/rio/sistema-brtcompleta-5-anos-sem-motivos-para-comemorar-21439782

Mao, B. (2008). Analysis on Transport Policies of Post-Olympic Times of Beijing. Journal of Transportation Systems Engineering and Information Technology, 8(6), 138-145. doi:10.1016/S1570-6672(09)60011-8

McKay, S., Murray, M., \& Macintyre, S. (2012). Justice as Fairness in Planning Policy-Making. International Planning Studies, 17(2), 147-162. doi:10.1080/13563475.2012.672798

Mello, K. (2016, April 6). Alerj aprova empréstimo para conclusão da Linha 4 do Metrô do Rio. Rio de Janeiro. Retrieved from http://g1.globo.com/rio-de-janeiro/noticia/2016/04/alerjaprovada-emprestimo-para-conclusao-da-linha-4-do-metro-do-rio.html

Minis, I., \& Tsamboulas, D. A. (2008). Contingency Planning and War Gaming for the Transport Operations of the Athens 2004 Olympic Games. Transport Reviews, 28(2), 259-280. doi:10.1080/01441640701628685 
Minnaert, L. (2012). An Olympic legacy for all? The non-infrastructural outcomes of the Olympic Games for socially excluded groups (Atlanta 1996-Beijing 2008). Tourism Management, 33(2), 361-370. doi:10.1016/j.tourman.2011.04.005

Müller, M. (2015). The Mega-Event Syndrome: Why So Much Goes Wrong in Mega-Event Planning and What to Do About It. Journal of the American Planning Association, 81(1), 6-17. doi:10.1080/01944363.2015.1038292

Neutens, T. (2015). Accessibility, equity and health care: review and research directions for transport geographers. Journal of Transport Geography, 43, 14-27. doi:10.1016/j.jtrangeo.2014.12.006

Neutens, T., Schwanen, T., Witlox, F., \& Maeyer, P. D. (2010). Equity of urban service delivery: a comparison of different accessibility measures. Environment and Planning A, 42(7), 1613 - 1635. doi:10.1068/a4230

O Globo. (2016). Falhas na racionalização das linhas de ônibus. Editorial - 20/02/2016. O Globo. Retrieved from http://oglobo.globo.com/opiniao/falhas-na-racionalizacao-das-linhas-deonibus-18712277

Paddison, R. (1993). City Marketing, Image Reconstruction and Urban Regeneration. Urban Studies, 30(2), 339-349. doi:10.1080/00420989320080331

Pereira, Rafael H. M., Schwanen, T., \& Banister, D. (2017). Distributive justice and equity in transportation. Transport Reviews, 37(2), 170-191. doi:10.1080/01441647.2016.1257660

Pereira, Rafael Henrique Moraes, \& Schwanen, T. (2013). Commute Time in Brazil (1992-2009): differences between metropolitan areas, by income levels and gender (p. 29). Institute for Applied Economic Research - Ipea. Retrieved from http://repositorio.ipea.gov.br/handle/11058/964

Pereira, Rafael Henrique Moreas, Banister, D., Schwanen, T., \& Wessel, N. (2017). Distributional effects of transport policies on inequalities in access to opportunities in Rio de Janeiro. SocArXiv. doi:10.17605/OSF.IO/CGHX2

Pillay, U., \& Bass, O. (2008). Mega-events as a Response to Poverty Reduction: The 2010 FIFA World Cup and its Urban Development Implications. Urban Forum, 19(3), 329-346. doi:10.1007/s12132-008-9034-9

Préteceille, E., \& Cardoso, A. (2008). Río de Janeiro y Sao Paulo: ¿ciudades duales? comparación con Paris. Ciudad Y Territorio: Estudios Territoriales, (158), 617-640.

Preuss, H. (2007). The Conceptualisation and Measurement of Mega Sport Event Legacies. Journal of Sport \& Tourism, 12(3-4), 207-228. doi:10.1080/14775080701736957

Raco, M. (2014). Delivering Flagship Projects in an Era of Regulatory Capitalism: State-led Privatization and the London Olympics 2012. International Journal of Urban and Regional Research, 38(1), 176-197. doi:10.1111/1468-2427.12025

Rawls, J. (1999). A theory of justice (revised edition.). Cambridge, Mass.: Belknap Press of Harvard University Press.

Rawls, J. (2001). Justice as fairness : a restatement. Cambridge, Mass; London: Harvard University Press. 
Rezende, V., \& Leitão, G. (2003). Plano Piloto para a Barra da Tijuca e Baixada de Jacarepaguá, a avaliação dos ideais modernistas após três décadas. In XVII Congresso Brasileiro de Arquitetos, Rio de Janeiro. Retrieved from http://xa.yimg.com/kq/groups/21776930/1339371762/name/PET+plano+piloto+Barra+B aixada+Jaca+EAU-UFF.pdf

Ribeiro, L. C. de Q. (Ed.). (2014). The Metropolis of Rio de Janeiro: a space in transition (1st ed.). Rio de Janeiro: Letra Capital.

Ribeiro, L. C. de Q., Rodrigues, J. M., \& Corrêa, F. S. (2010). Segregação residencial e emprego nos grandes espaços urbanos brasileiros. Cadernos Metrópole. ISSN (impresso) 15172422; (eletrônico) 2236-9996, 12(23). Retrieved from http://revistas.pucsp.br/index.php/metropole/article/view/5921

Rio de Janeiro. (1996). Strategic Plan for the City of Rio de Janeiro - Rio Forever Rio. Rio de Janeiro: City Hall of Rio de Janeiro.

Rio de Janeiro. (2005). Plano diretor de transporte urbano da região metropolitana do Rio de Janeiro. Relatório 2 - analise de estudos e planos existentes. Revisão 2. Rio de Janeiro: Governo do Estado. Secretaria de Estado de Transportes. Retrieved from http://download.rj.gov.br/documentos/10112/1474054/DLFE59250.pdf/Relatorio02AnaliseEstudosExistentes.pdf

Rio de Janeiro. (2008). Plano de Legado Urbano e Ambiental: Olimpíadas Rio 2016. Rio de Janeiro: Comitê Especial de Legado Urbano - Secretaria Municipal de Urbanismo. Retrieved from http://www.rio.rj.gov.br/web/smu/exibeconteudo?article-id=138922

Rio de Janeiro. (2014). Atualização do Plano Diretor de Regionalização - 2012 / 2013. Secretaria Estadual de Saúde do Estado do Rio de Janeiro. Retrieved from http://www.saude.rj.gov.br/component/docman/?task=doc_download\&gid=9794\&Itemid $=1214$

Rio de Janeiro. (2015). Explaining Rio de Janeiro habitational policy. Rio de Janeiro: City Hall of Rio de Janeiro. Retrieved https://drive.google.com/file/d/0B1x0_cNhKxbDb094M1hraGVNekU/view

Rio de Janeiro. (2016). Rio 2016: Jogos Olímpicos e legado - Cadernos de políticas públicas. Rio de Janeiro: City Hall of Rio de Janeiro.

Ritchie, J. R. B. (1984). Assessing the Impact of Hallmark Events: Conceptual and Research Issues. Journal of Travel Research, 23(1), 2-11. doi:10.1177/004728758402300101

Robbins, D., Dickinson, J., \& Calver, S. (2007). Planning transport for special events: a conceptual framework and future agenda for research. International Journal of Tourism Research, 9(5), 303-314. doi:10.1002/jtr.639

Roche, M. (1994). Mega-events and urban policy. Annals of Tourism Research, 21(1), 1-19. doi:10.1016/0160-7383(94)90002-7

Rodrigues, J. M., \& Legroux, J. (2015). A questão da mobilidade urbana na Região Metropolitana do Rio de Janeiro: reflexões a partir dos projetos de infraestrutura para megaeventos 
esportivos. In D. G. Castro et al. (Ed.), Rio de Janeiro. Os impactos da copa do mundo 2014 e das Olimpíadas 2016 (1st ed.). Rio de Janeiro: Letra Capital.

Rodrigues, M. (2016). Após 5 meses, usuários reprovam racionalização de ônibus no Rio 03/03/2016. G1 Rio Globo.com. Retrieved from http://g1.globo.com/rio-dejaneiro/noticia/2016/03/apos-5-meses-usuarios-reprovam-racionalizacao-de-onibus-norio.html

Rodrigues, R. (2017, June 28). Metrô faz oferta promocional após queda de 14,5\% nas viagens Jornal O Globo. Retrieved from https://oglobo.globo.com/rio/metro-faz-ofertapromocional-apos-queda-de-145-nas-viagens-21527565

Rubalcaba-Bermejo, L., \& Cuadrado-Roura, J. R. (1995). Urban Hierarchies and Territorial Competition in Europe: Exploring the Role of Fairs and Exhibitions. Urban Studies, 32(2), 379-400. doi:10.1080/00420989550013149

Sánchez, F., \& Broudehoux, A.-M. (2013). Mega-events and urban regeneration in Rio de Janeiro: planning in a state of emergency. International Journal of Urban Sustainable Development, 5(2), 132-153. doi:10.1080/19463138.2013.839450

Sandy, M. (2016, March 24). The Rio Olympics Could Be the Next Victim of Brazil's Corruption Scandal. Time. Retrieved from http://time.com/4271376/brazil-corruption-scandalolympics/

Santos, R. R. de O. (2013, September 30). O planejamento da cidade é o planejamento dos jogos? O megaevento olímpico como instrumento de (re)ordenação do território carioca (text). Universidade de São Paulo. Retrieved from http://www.teses.usp.br/teses/disponiveis/16/16139/tde-06012014-160038/

Shin, H. B., \& Li, B. (2013). Whose games? The costs of being “Olympic citizens" in Beijing. Environment and Urbanization, 0956247813501139. doi:10.1177/0956247813501139

Short, J. R. (2008). Globalization, cities and the Summer Olympics. City, 12(3), 321-340. doi:10.1080/13604810802478888

Silva, M. A. V. da, \& Portugal, L. da S. (2016). Location factors affecting trip generation during megaevents. Proceedings of the Institution of Civil Engineers - Municipal Engineer, 1-14. doi:10.1680/jmuen.16.00014

Silvestre, G. (2012). An Olympic city in the making: Rio de Janeiro mega-event strategy 19932016. IOC Olympic Studies Centre. Retrieved from http://doc.rero.ch/record/32218

Smith, A. (2009). Theorising the Relationship between Major Sport Events and Social Sustainability. Journal of Sport \& Tourism, 14(2-3), 109-120. doi:10.1080/14775080902965033

Souza, P. H. G. F. de. (2015). Income distribution according to Brazilian household surveys: harmonization and comparison of Census, PNAD and POF data. Revista Brasileira de Estudos de População, 32(1), 165-188. doi:10.1590/S0102-30982015000000009

Steinbrink, M., Haferburg, C., \& Ley, A. (2011). Festivalisation and urban renewal in the Global South: socio-spatial consequences of the 2010 FIFA World Cup. South African Geographical Journal, 93(1), 15-28. doi:10.1080/03736245.2011.567827 
Stewart, A., \& Rayner, S. (2016). Planning mega-event legacies: uncomfortable knowledge for host cities. Planning Perspectives, 31(2), 157-179. doi:10.1080/02665433.2015.1043933

Tomlinson, A. (2014). Olympic legacies: recurrent rhetoric and harsh realities. Contemporary Social Science, 9(2), 137-158. doi:10.1080/21582041.2014.912792

UN HABITAT. (2013). Planning and Design for Sustainable Urban Mobility: Global Report on Human Settlements 2013. London: Routledge: UN HABITAT. Retrieved from http://www.unhabitat.org/pmss/listItemDetails.aspx?publicationID=3503

UN-HABITAT. (2010). State of the World's Cities 2010/2011- Cities for All: Bridging the Urban Divide (p. 244). UN-HABITAT. Retrieved from http://unhabitat.org/books/state-of-theworlds-cities-20102011-cities-for-all-bridging-the-urban-divide/

Van Wee, B. (2012). How suitable is CBA for the ex-ante evaluation of transport projects and policies? A discussion from the perspective of ethics. Transport Policy, 19(1), 1-7. doi:10.1016/j.tranpol.2011.07.001

Van Wee, B., \& Geurs, K. (2011). Discussing equity and social exclusion in accessibility evaluations. European Journal of Transport and Infrastructure Research, 11(4). Retrieved from http://www.ejtir.tbm.tudelft.nl/issues/2011_04/abstracts/2011_04_01.asp

Vanwynsberghe, R., Surborg, B., \& Wyly, E. (2013). When the Games Come to Town: Neoliberalism, Mega-Events and Social Inclusion in the Vancouver 2010 Winter Olympic Games. International Journal of Urban and Regional Research, 37(6), 2074-2093. doi:10.1111/j.1468-2427.2012.01105.x

Weed, M., Coren, E., Fiore, J., ... Dowse, S. (2015). The Olympic Games and raising sport participation: a systematic review of evidence and an interrogation of policy for a demonstration effect. European Sport Management Quarterly, 15(2), 195-226. doi:10.1080/16184742.2014.998695

Wessel, N., Allen, J., \& Farber, S. (2017). Constructing a routable retrospective transit timetable from a real-time vehicle location feed and GTFS. Journal of Transport Geography, 62, 9297. doi:10.1016/j.jtrangeo.2017.04.012

Whitson, D., \& Horne, J. (2006). Part 2 The Glocal Politics of Sports Mega-Events: Underestimated costs and overestimated benefits? Comparing the outcomes of sports mega-events in Canada and Japan. The Sociological Review, 54, 71-89. doi:10.1111/j.1467-954X.2006.00654.X

Xu, Y., \& Gonzalez, M. C. (2016). Collective benefits in traffic during mega events via the use of information technologies. arXiv:1607.08203 [Physics]. Retrieved from http://arxiv.org/abs/1607.08203

Zarur, C. (2017). Empresa de ônibus do Rio fecha por causa da crise. Retrieved October 5, 2017, from https://extra.globo.com/noticias/rio/empresa-de-onibus-do-rio-fecha-por-causa-dacrise-21258317.html

Zhang, L., \& Zhao, S. X. (2009). City branding and the Olympic effect: A case study of Beijing. Cities, 26(5), 245-254. doi:10.1016/j.cities.2009.05.002 